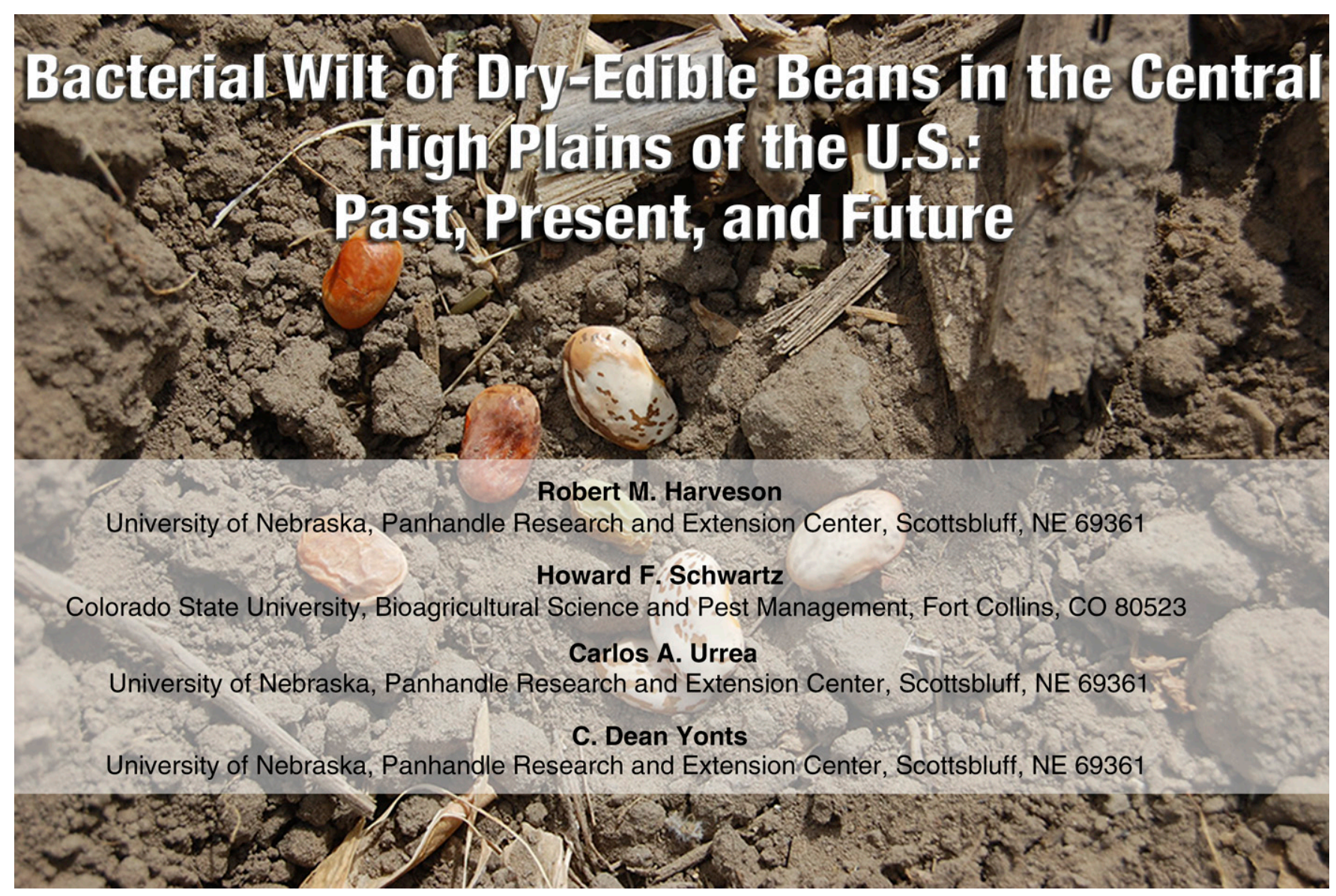

\section{Discovery and Background}

Bacterial wilt, caused by Curtobacterium flaccumfaciens pv. flaccumfaciens, was first recognized and described as a new dry bean disease near Redfield, SD after the 1921 growing season on the farm of the Office of Forage Investigations (Hedges 1922, 1926a). The grower on this farm informed the federal investigators that he believed the disease to be the same one that killed $90 \%$ of his crop in 1920. For the 1921 season, he saved and planted the seed harvested from the previous year, resulting in an estimated 25\% loss (Hedges 1926a).

\section{First Investigations of Bacterial Wilt}

As head of the primary pathology laboratory within the USDA's Bureau of Plant Industry (BPI) in Washington D.C., Erwin F. Smith assigned to Florence Hedges the task of investigating this new disease outbreak (Harveson 2013, 2015). She was a recent graduate of the University of Michigan, and one of more than 20 women scientists who worked in Smith's lab during his tenure in the USDA (Fig. 1) (Ristaino 2008).

Hedges' first attempt in addressing the problem included planting a portion of the seeds collected from surviving plants originating from the devastated 1920 South Dakota crop in plots in Arlington, VA. This exercise resulted in a large number of diseased plants, many of which never survived beyond the seedling stage. After examining plants from both South Dakota and the experimental planting in Virginia, she discovered bacteria within the stem vessels, a condition that was also accompanied by vascular browning. Diseased plants

Accepted for publication 21 July 2015.

http://dx.doi.org/10.1094/PDIS-03-15-0299-FE

(C) 2015 The American Phytopathological Society wilted and consistently yielded a Gram-positive, yellow bacterium from the vascular system.

Hedges fulfilled Koch's postulates after repeated artificial inoculations with isolates from both the newly infected 1921 fieldgrown beans from South Dakota, and from the infected beans planted in Arlington, VA that were originally obtained from the 1920 crop from the same farm in Redfield, SD. The isolated organism from both sites was noted to be different from all other previously known pathogens, and named Bacterium flaccumfaciens (Hedges 1922, 1926a).

After the initial discovery in South Dakota, Hedges continued to find the disease in other locations, isolating the same pathogen from wilted navy bean plants grown in Michigan, Virginia, and Maryland, and from seed collected from Montana, Michigan, Maryland, the District of Columbia, France, and Germany (Hedges 1926a). Based on these findings in the early 1920s, she hypothesized that the disease appeared to be widely distributed throughout bean growing areas, but had perhaps been previously confused with the more familiar bacterial disease called common blight (Hedges 1926a).

\section{Further Incidence and Distribution of the Disease Within the United States}

Within the United States, bacterial wilt was reported sporadically after Hedges' initial reports. Between the late 1930s and the early 1950s it became one of the more problematic bacterial diseases of dry beans, particularly in the irrigated high plains and western United States bean-growing states (Harveson 2013, 2015). It was first noted in Wyoming in 1937, and continued to cause serious reductions in yield near Riverton, WY throughout the 1940s (Zaumeyer and Thomas 1957). Surveys conducted from other production areas of Wyoming at this time found the bacterium occurring in $35 \%$ of fields, and in combination with the common blight pathogen (Xanthomonas axonopodis pv. phaseoli) in another 
$28 \%$ of surveyed fields (Burke 1957a; Burke and Seliskar 1957; Zaumeyer and Thomas 1957).

In 1947, the disease was first observed in Idaho and Colorado, but it was not considered to be problematic at that time (Zaumeyer and Thomas 1957). However, later in the early 1950s, many pinto fields in northeastern Colorado were abandoned as total losses directly attributed to this disease (Burke 1957a; Burke and Seliskar 1957). Wilt was first observed in 1948 in Nebraska and the Columbia Basin of Washington in 1951 (Harveson 2013; Schuster and Coyne 1974, 1975; Zaumeyer and Thomas 1957).

\section{Pathogen Taxonomic History}

K. B. Lehmann and R. O. Neumann created the genus Corynebacterium in 1896 to taxonomically house the diphtheria bacterium, C. diphtheria (Lehmann and Neumann 1896). Other similar animal pathogens were placed into this genus, followed by the addition of an increasingly wide array of newly identified, but superficially similar bacteria (Vidaver 1982; Vidaver and Starr 1981). Thus this genus became a catch-all repository for an eclectic group of Gram-positive, pleomorphic bacteria.

The Danish microbiologist Hans Jensen first noticed and pointed out the similarity of certain common soil coryneform bacteria with two specific plant pathogens, including those causing alfalfa wilt and tomato canker (Jensen 1934, 1952). He then proposed that these two phytopathogenic bacteria be transferred to the genus Corynebacterium, reclassifying them as $C$. insidiosum and C. michiganense, for the alfalfa and tomato pathogens respectively (Jensen $1934,1952)$. Jensen also created the term "coryneform" as a reference for members of this group in general. It is still widely used today to informally describe representatives of a heterogeneous group of Gram-positive bacteria with cell morphological features consisting of irregular, short rods (Fig. 2) that may also be slightly curved, bent, or club-shaped (Davis 1986, 2001). These morphological traits are the origin for the genus name, derived from the Greek noun "koruna" or "club."

Members of the plant pathogenic genus Corynebacterium causing wilt diseases of numerous crops were subdivided into two groups based on several differing characteristics. One group included the previously mentioned $C$. insidiosum and $C$. michiganense as slow growing, nonmotile bacteria incapable of growth at temperatures above $35^{\circ} \mathrm{C}$, and were transferred to the genus Clavibacter (Collins and Jones 1983). The other group contained

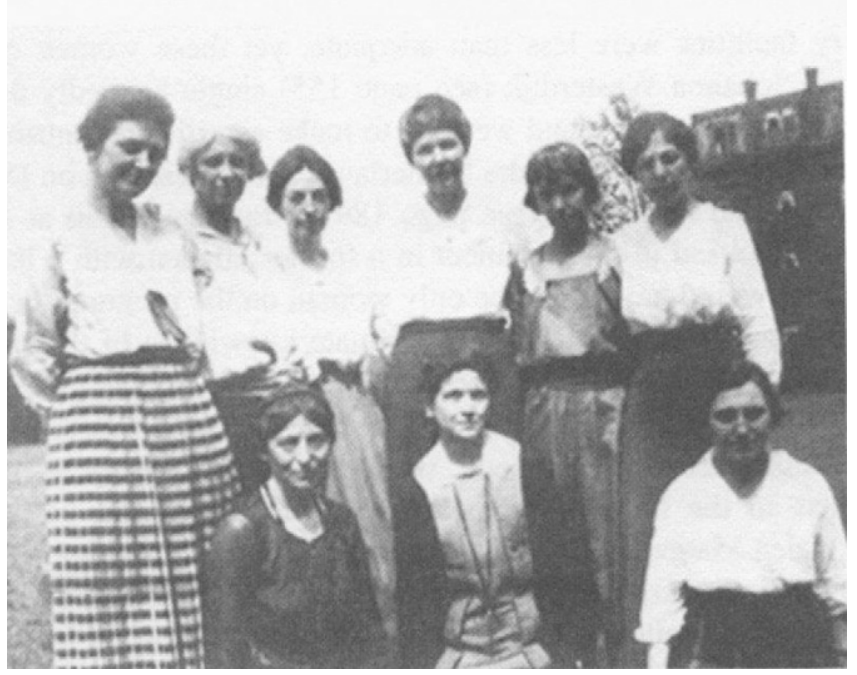

Fig. 1. Women scientists working in the lab of E. F. Smith in 1921. From left to right: Standing: Charlotte Elliott, Hellie A. Brown, Edith Cash, Mary Katharine Bryan, Anna Jenkins, and Lucia McCulloch. Seated: Florence Hedges, Pearle Smith, and Angie Beckwith. Photo credit: National Archives and Records Administration, Washington D.C. Also published as Fig. 6 in: Pioneering Women in Plant Pathology, 2008 (APS Press). the bean wilt pathogen $C$. flaccumfaciens as bacteria that grew more rapidly on nutrient media, had polar flagella, and grew at 35 to $37^{\circ} \mathrm{C}$. Corynebacterium flaccumfaciens was then transferred into the new genus Curtobacterium on the basis of biochemical and DNA characteristics and cell wall composition that differed from the Clavibacter group (Collins and Jones 1983). This new genus name was created as a result of its characteristic cell shape. The name Curtobacterium is derived from the Latin word "cutus" or "shortened" to describe a short bacterium or rod (Fig. 2). Florence Hedges gave the bean wilt pathogen its species name after her description of its most distinguishing characteristic (Hedges 1926a). The specific epithet, flaccumfaciens, is derived from the Latin word "flaccus" meaning "flabby or flaccid", and "faciens" meaning "making," thus describing the pathogenic actions of the bacterium and resulting symptoms as "wilt-making."

\section{New Reports and Recent History}

After being identified in Wyoming, Colorado, and Nebraska in the 1930 s and 1940s, bacterial wilt was infrequently, but repeatedly observed occurring as field infections in this region of the United States. It became an endemic problem in dry bean production throughout western Nebraska and other areas of the central high plains (southeastern Wyoming and northeastern Colorado) during the 1960s and early 1970s, presumably through seedborne transmission and dissemination (Harveson 2015; Hedges 1926b; Schuster and Coyne 1974). By the early 1980s, the disease had virtually disappeared with the implementation of cultural practices such as sanitation, rotation, and planting clean, disease-free seed (Harveson 2015; Harveson and Schwartz 2007).

In mid-August 2003, plants exhibiting wilting and irregular, interveinal necrotic foliar lesions surrounded by a bright yellow border were found in three dry bean fields (market class great northern) in Scotts Bluff Co., NE (Harveson 2013, 2015; Harveson et al. 2006). The incidence and spread of the disease in one particular field in the Gering Valley was first observed several days after a severe hailstorm, its damage associated with the storm path, moving from the southwest to the northeast (Fig. 3). During this same period, in another field in Northern Scotts Bluff County, bean plants were observed wilting and dying as individual, isolated plants in a pattern suggesting seed infection (Harveson et al. 2006, 2011).

\section{Epidemic}

Based on the history of rare occurrences of the pathogen, the findings in 2003 were assumed to be an isolated and unique event. However, in 2004 the disease was again observed in two yellow bean

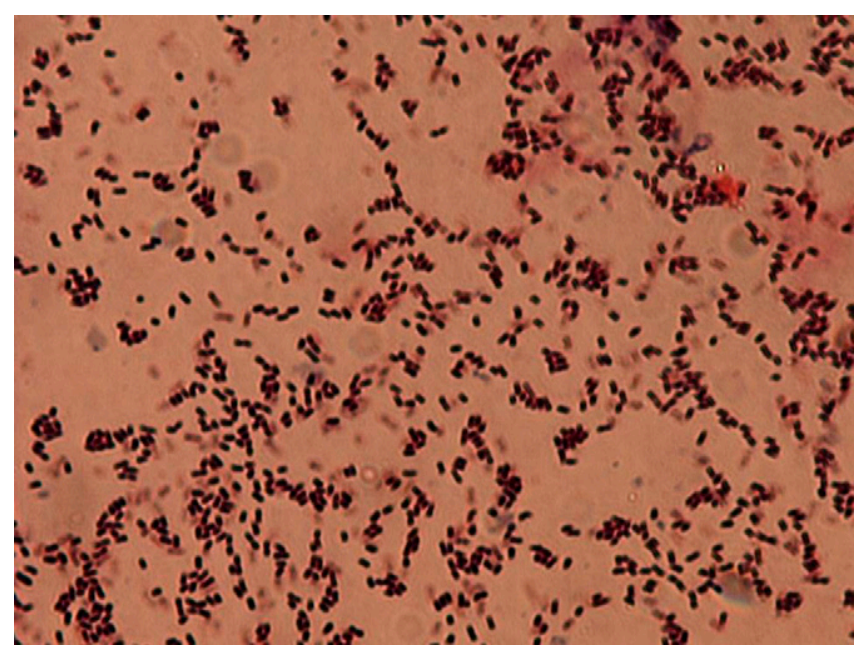

Fig. 2. Characteristic morphological features of Curtobacterium flaccumfaciens $p v$. flaccumfaciens consisting of short, fat, Gram-positive rods that stain a purple to black color (magnification 400x). 
(cv. Enola) fields in the Gering Valley in early August. One had been badly damaged by hail, with the other escaping serious storm damage. Nevertheless, both fields were still deleteriously affected by the disease, but the hailed field was noticeably worse.

The yellow bean variety 'Enola' proved to be particularly susceptible, and at that time was being widely planted in the region due to increased interest and demand for that particular market class. The high incidence of disease in these crops provided the stimulus for investigating additional market classes in other fields throughout the region. After a quickly implemented survey in late August and early September 2004, dry bean plants exhibiting identical symptoms were additionally observed in more than 40 dry bean fields in western Nebraska, representing four separate counties (Scotts Bluff, Box Butte, Sheridan, and Morrill), including fields planted with yellow, light red kidney, great northern, and pinto market classes (Harveson 2013; Harveson et al. 2006; Harveson and Schwartz 2007).

The occurrence of wilt during these two seasons were designated as the first reports in the high plains and Nebraska in over 30 years, and the only contemporary report in North America of infection occurring in the field prior to harvest (Harveson et al. 2006). Other recent reports in North Dakota and Canada were based on discolored seeds collected after harvest in processing plants (Hsieh et al. 2002; Huang et al. 2006; Venette et al. 1995).

\section{Pathogen Identification}

Isolations from both 2003 and 2004 were made from leaf and stem tissues, and from seeds collected after harvest from infected plants, all resulting in high, nearly pure populations of a bacterium morphologically characteristic of the wilt pathogen, and typical in pigment, texture, and form. Colonies were Gram-positive, slow-growing, creamy yellow or orange, and fluidal (Fig. 4) on nutrient broth yeast extract (NBY) medium, becoming darker with age (Harveson et al. 2006; Harveson and Schwartz 2007). The bacterium was identified as $C$. flaccumfaciens pv. flaccumfaciens based on cell morphology (coryneform-shaped, motile rods), positive Gram stain and $\mathrm{KOH}$ reactions, fatty acid profiles, and Biolog carbon source utilization profiles.

\section{Signs and Symptoms}

Initial disease symptoms in the field consist of leaf wilting (Fig. 5) during periods of warm, dry weather or periods of moisture stress, due to the pathogen's presence within the vascular system, which blocks normal water movement from roots into the foliage. Plants often recover during evening hours when temperatures are lower, but wilt again during the heat of the day. Disease severity and plant mortality are often higher on young plants or those growing from infected seed (Harveson et al. 2011). Seedlings are particularly susceptible, and if attacked when they are 5 to $7.5 \mathrm{~cm}$ tall, they are usually killed (Fig. 6). Symptoms on older plants are less

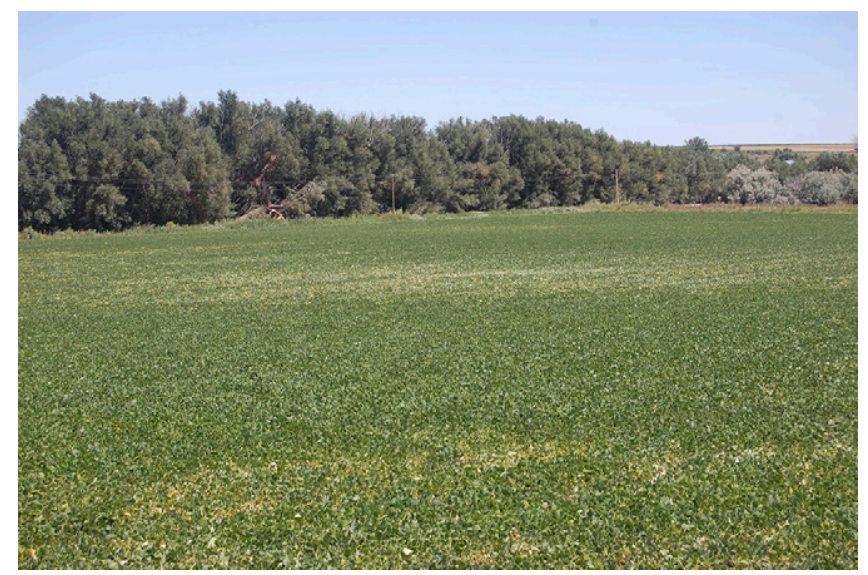

Fig. 3. Spread of bacterial wilt in a dry bean field in a pattern corresponding to previous storms moving southwest to northeast. View of photo is looking northwest. pronounced as the disease generally develops and progresses more slowly.

Infected plants in the central high plains have additionally exhibited field symptoms consisting of interveinal, necrotic lesions surrounded by bright yellow borders, referred to as "firing" (Fig. 7) (Harveson 2013; Harveson et al. 2011; Harveson and Schwartz 2007; Schwartz et al. 2005). These symptoms may be confused with those caused by the common bacterial blight pathogen, Xanthomonas axonopodis pv. phaseoli (Fig. 8). However, bacterial wilt lesions

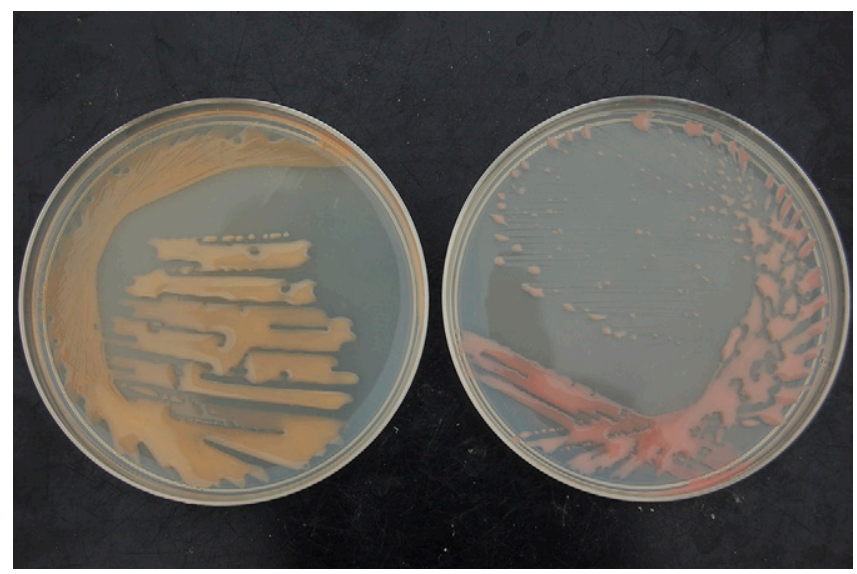

Fig. 4. Yellow (left) and orange (right) color variants of Curtobacterium flaccumfaciens pv. flaccumfaciens nutrient broth yeast extract medium (NBY). Cultures are approximately 1 week old and colors will darken with age.

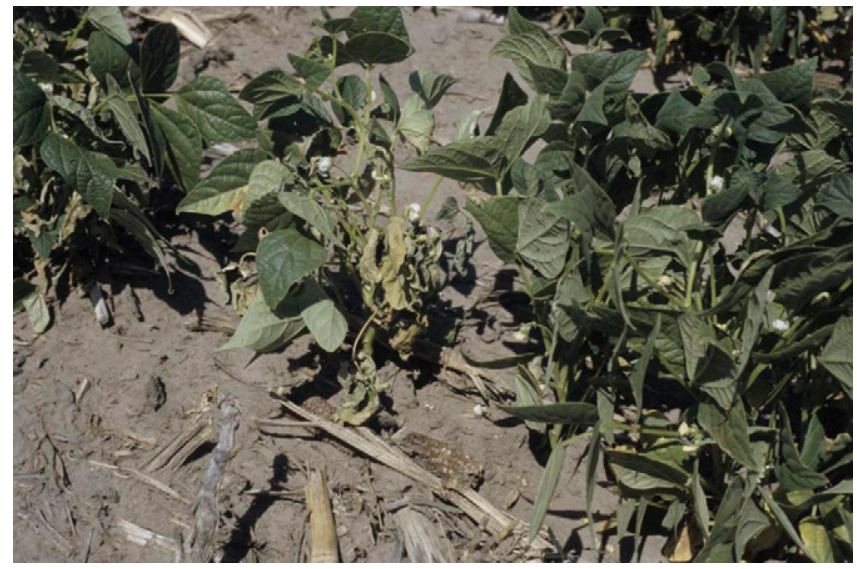

Fig. 5. Leaf wilting symptoms on dry beans due to bacterial bean wilt.

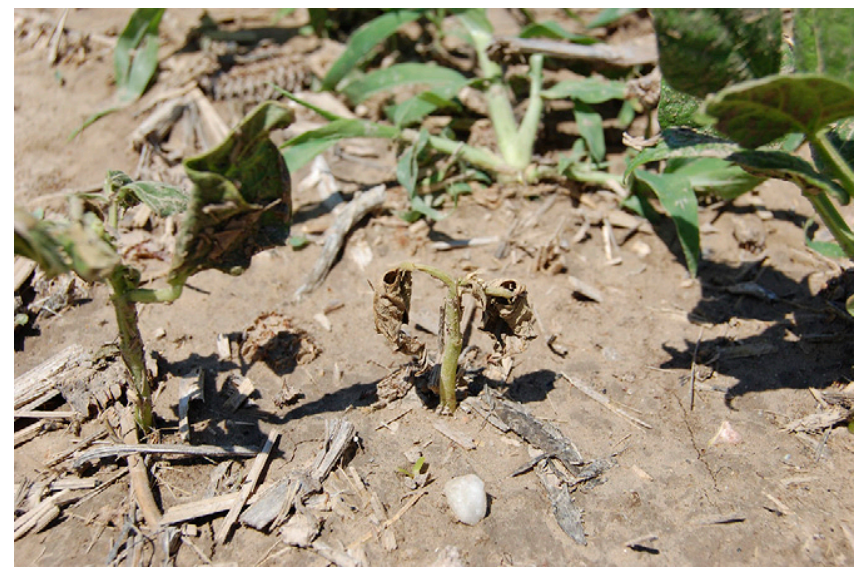

Fig. 6. Death of a dry bean seedling due to bacterial wilt. 
tend to be more wavy or irregular (Fig. 7), and are additionally accompanied by wilting and often death of severely infected plants (Fig. 9) (Harveson et al. 2011; Schwartz et al. 2005). Common bacterial blight-infected plants are rarely killed, and wilting does not occur as a part of the disease process.

For formal identification, laboratory analyses (Gram stain reaction and cell morphology) are more definitive. However, as a rule of thumb, preliminary field diagnosis of wilt should include both wilting and firing symptoms. Additionally, water soaking of leaves is not always observed with wilt as it is with other bacterial diseases (common bacterial blight, halo blight, caused by Pseudomonas syringae pv. phaseoli, or bacterial brown spot, caused by $P$. syringae pv. syringae), except on the highly susceptible wilt-infected yellow bean leaves in Colorado (Fig. 10) (Harveson et al. 2011; Harveson and Schwartz 2007; Schwartz et al. 2005).

\section{Conditions Favoring Disease}

The wilt disease of dry beans, as with many other bacterial diseases, is favored by a number of similar conditions that promote

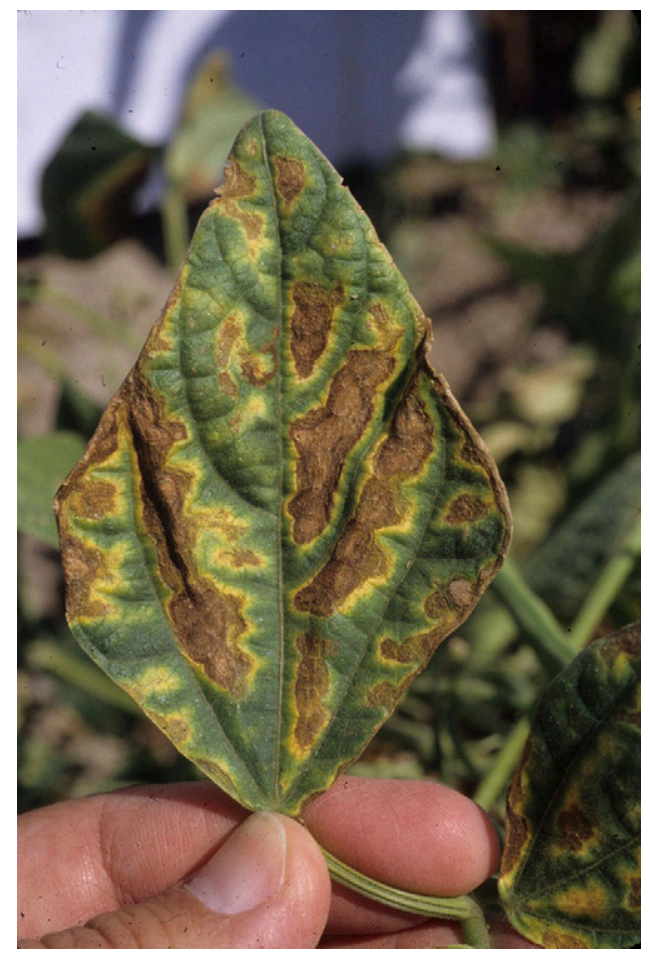

Fig. 7. Interveinal necrotic symptoms with irregular yellow haloes (firing), characteristic of bean wilt.

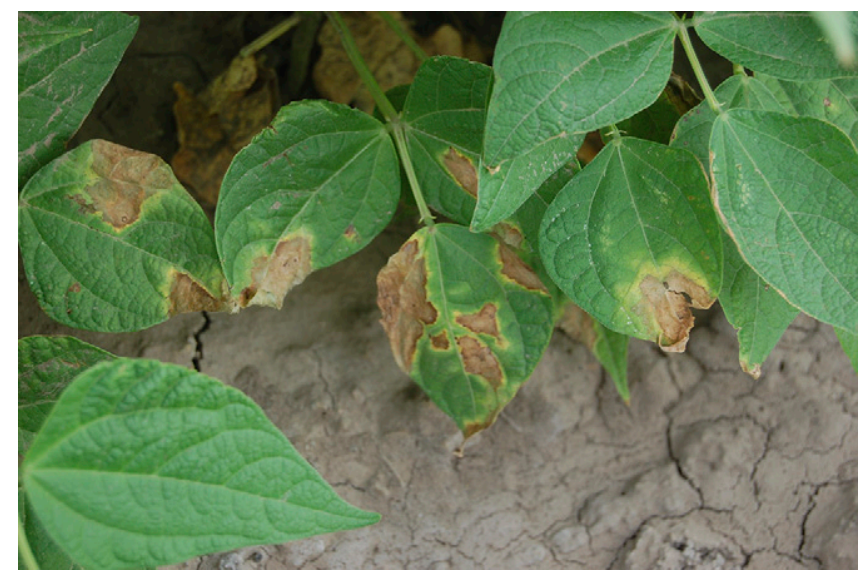

Fig. 8. Marginal necrosis and yellowing symptoms associated with common bacterial blight, caused by Xanthomonas axonopodis pv. phaseoli. new infections and secondary spread in the field. These include planting infected seed, planting beans in close proximity to infected fields from the previous year, using reduced tillage methods of land preparation, and environmental conditions involving high levels of leaf moisture (Ishimaru et al. 2005; Schwartz et al. 2005). Disease development is also favored by high temperatures $\left(>30^{\circ} \mathrm{C}\right)$, with optimal pathogen growth in culture occurring at 27 to $28^{\circ} \mathrm{C}$ (Davis 2001; EPPO/CABI 1997; Vidaver 1982; Vidaver and Starr 1981).

In addition, bacterial wilt is enhanced by any factor that wounds bean plants, such as storms, hail events, or any other physical damage from humans, animals, or farm equipment (Harveson et al. 2011; Schwartz et al. 2005). Bacteria cannot penetrate intact plant surfaces, but instead require either natural openings in leaves or wounding for initiating infection. Storms with high winds, driving rain, and hail provide the perfect opportunity for bacteria to become established because they can cause wounding (Fig. 11) and physically move the pathogen and/or infected plant parts between and within fields. Burke first demonstrated experimentally that significant losses attributable to bacterial pathogens often occurred after hailstorms and that losses were most extensive in fields where beans were grown regularly (Burke 1957a; Burke and Seliskar 1957). Burke also demonstrated that infection still could occur in fields growing beans for the first time, even with certified disease-free seed (Burke 1957b; Burke and Seliskar 1957).

\section{Ecology, Infection, and Survival}

Seed transmission and pathogen survival. Hedges (1926b) provided the first evidence of seedborne infection and transmission for

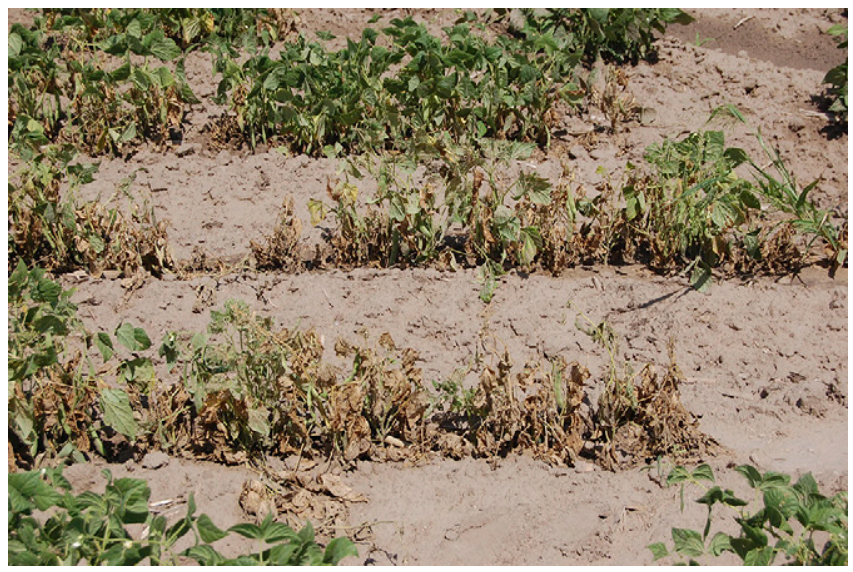

Fig. 9. Great northern dry bean field in Nebraska severely affected by bacterial wilt.

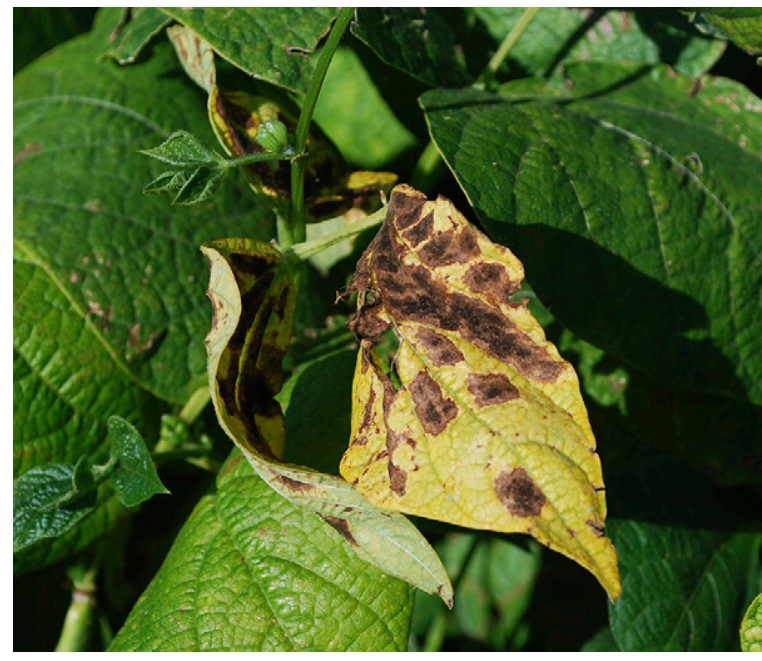

Fig. 10. Water-soaking symptoms on yellow beans due to bacterial wilt. 
the bean wilt organism. The first report from Idaho in 1947 was noted from several snap bean seed fields where severe infection and yield losses occurred. These outbreaks originated from diseased plants grown from the same seed lot planted the year before. That same year in Wyoming, severe losses exceeding $60 \%$ were documented in a field planted to beans the previous year while trace levels of the disease were observed in several other fields planted previously to other crops (Zaumeyer and Thomas 1947). Although the source of infection was never established conclusively, all fields in question utilized certified seed produced in Idaho, indicating, as Hedges postulated 20 years earlier, that infected seed presumably served as the mechanism for pathogen infestation and dissemination into new areas.

Longevity outside the host is a major challenge to plant pathogenic bacteria since most have minimal saprophytic competitive ability. In addition, unlike many fungi, bacterial plant pathogens do not form resting spores or other overwintering structures, allowing them to remain dormant. Therefore plant pathogenic bacteria depend upon other methods for survival such as colonization of plant debris, until the occurrence of environmental conditions that favor infection are restored (Leben 1981; Schuster and Coyne 1974, 1975).

Due to the seedborne nature of $C$. flaccumfaciens pv. flaccumfaciens, infected seeds represent the major source of inoculum and means for dispersal, both long and short distances (Zaumeyer and Thomas 1957). Infected seeds also provide an excellent mechanism for survival, both internally and on the external seed surface. The pathogen can also overwinter on infected plant residue or weeds, but survival in soil is poor (Schuster and Coyne 1974, 1975). Due to a strong resistance to drying, the pathogen has been demonstrated to remain viable up to 24 years in infected under laboratory conditions (Burkholder 1945).

\section{Disease Cycle}

Initial infection occurs when the pathogen enters the vascular system through either infected seed or through wounds on leaves or stems. Regardless of the initial infection source, bean wilt, in general, develops more rapidly and causes greater damage during periods of severe plant stresses including high temperatures, moisture deprivation, or mechanical damage of any kind. Wilting of plants is more severe during periods of moisture stress. After initial infection, secondary spread of bean wilt occurs in a manner like that of common bacterial and halo blights.

The systemic nature of the wilt disease was first demonstrated by Hedges (Hedges 1922, 1926a) and later proven formally by W. J. Zaumeyer through cytological studies (Zaumeyer 1932). If plants survive to produce mature seed, infection and systemic spread enables the pathogen to move through the vascular (xylem) system into developing pods and seed embryos, causing discoloring or

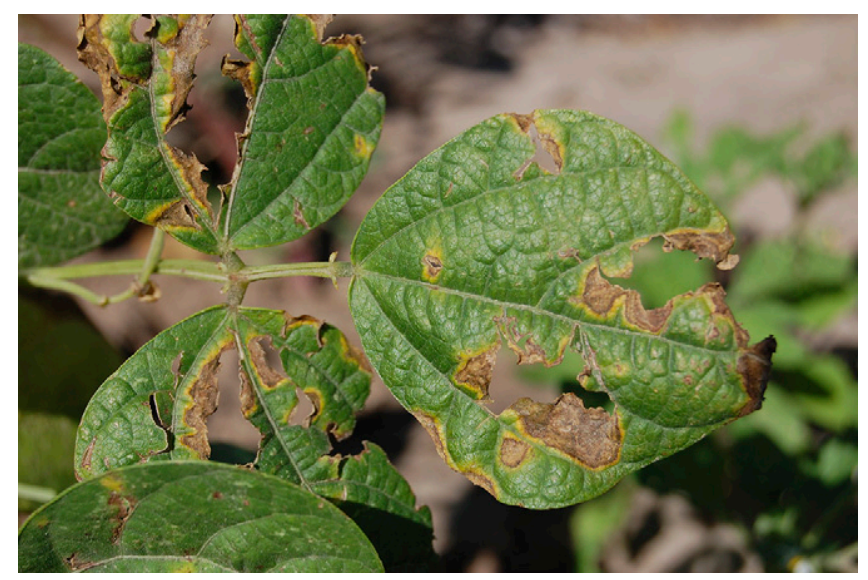

Fig. 11. Symptoms of bacterial wilt infection associated with hail damage on dry bean leaves. staining of seeds (Fig. 12). Staining of seeds can still occur, even while pods appear to remain healthy-looking with no external lesions. (Fig. 13).

The discoloration (infection) is particularly conspicuous on white seeded market classes such as navy or great northern beans. The sharply contrasting colors on infected seeds led directly to the discovery of different colored bacterial strains (often referred to as color variants) first in Nebraska (Harveson et al. 2011; Harveson and Schwartz 2007; Schuster and Christiansen 1957; Schuster et al. 1968), and later elsewhere (Hsieh et al. 2002; Huang et al. 2006; Venette et al. 1995). Infected seeds may be stained yellow, orange, purple, or pink (Fig. 14) (Harveson and Vidaver 2008; Hedges 1926a; Schuster and Christiansen 1957; Schuster and Sayre 1967; Schuster et al. 1968).

\section{Pathogen Color Variants}

The bacterial wilt pathogen is unique in its ability to produce isolates that vary in color. Colony growth of the original isolates from the eastern and midwestern United States was reported to be yellow (Fig. 15, bottom) but orange-stained seeds (Fig. 16) were first noted from cull samples collected from processing plants after harvest as part of a bacterial disease survey conducted in western Nebraska after the 1952 season (Schuster and Christiansen 1957). These discolored seeds yielded a bacterium that produced orange growth in culture (Fig. 15, right).

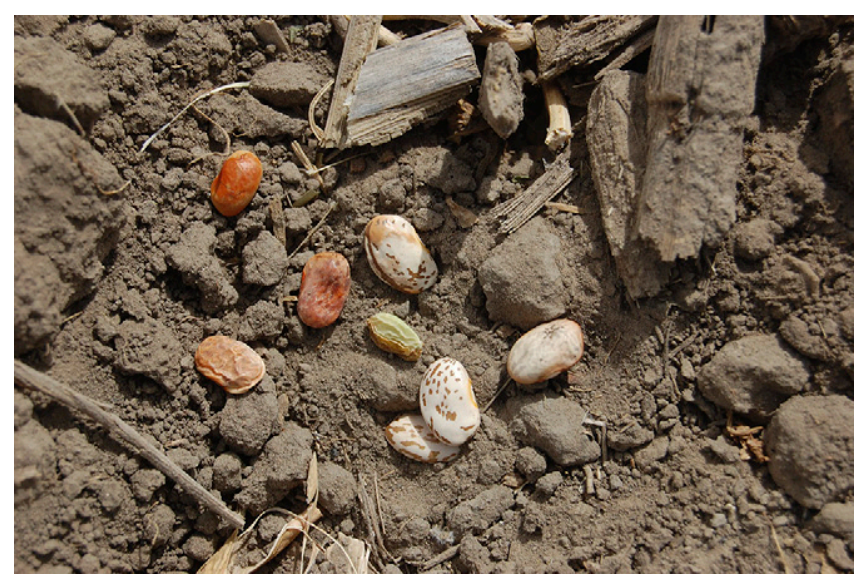

Fig. 12. Orange-stained pinto bean seeds from systemic infection by bacterial wilt that fell to the ground after harvest.

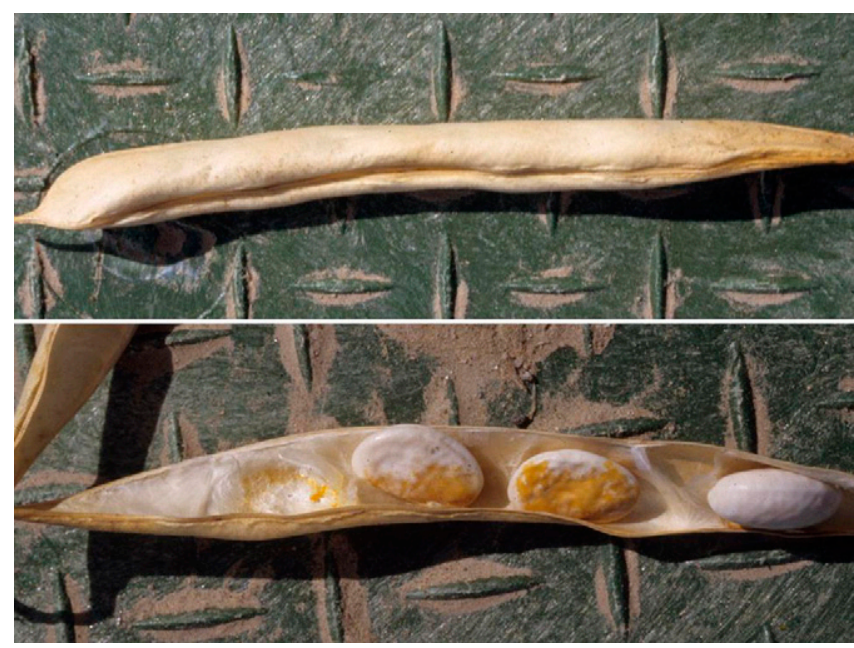

Fig. 13. One pod of bacterial wilt-infected dry bean plant showing discolored seeds (bottom) inside a pod with no external symptoms (top). Note that not all seeds are infected or discolored. 
Morphologically, physiologically, and serologically, the orange strains could not be distinguished from the original yellow strain other than by colony color, and these traits remained stable through multiple transfers and inoculations. Schuster designated this "strain" as C. flaccumfaciens var. auranticum (orangecolored) (Schuster and Christiansen 1957). It was not until 1967 that another Curtobacterium flaccumfaciens pv. flacumfaciens color variant was formerly identified and reported from western Nebraska (Schuster and Sayre 1967). White-seeded great northern beans staining a purplish color were found within cull bean samples after processing. This new color variant of the pathogen was named $C$. flaccumfaciens var. violaceae (violet-colored) (Schuster and Sayre 1967), and is different from the orange variant biologically. The purple variants tend to be less virulent, maintaining a yellow colored colony in culture, but produce a bright purple to blue water-soluble pigment that diffuses into growth medium (Fig. 15, left and Fig. 17) while also discoloring seed (Fig. 14, left) (Schuster and Sayre 1967; Schuster et al. 1968). The purple pigments produced by this variant are often unstable and inconsistently expressed in culture, which may explain this variant's lower reported incidence in nature. Without pigment production, these isolates are indistinguishable from many other yellow strains (Fig. 17). The purple variant is still very rare, and has only been reported once outside of the western Nebraska panhandle (Huang et al. 2006).

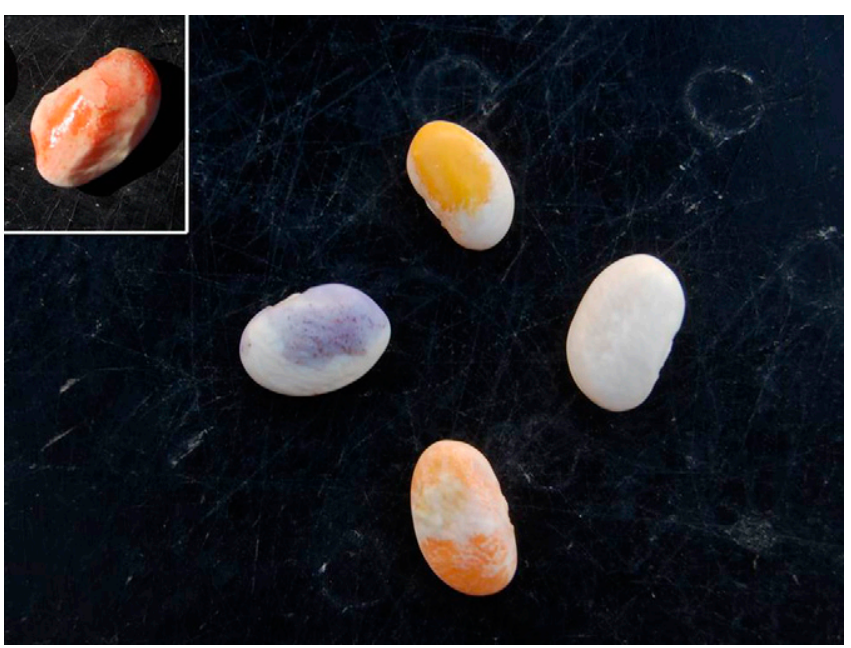

Fig. 14. Market class great northern dry bean seeds affected by pathogen color variants (reading clockwise from bottom) orange, purple, yellow, and uninfected. A pink-stained seed is also included in the inset.

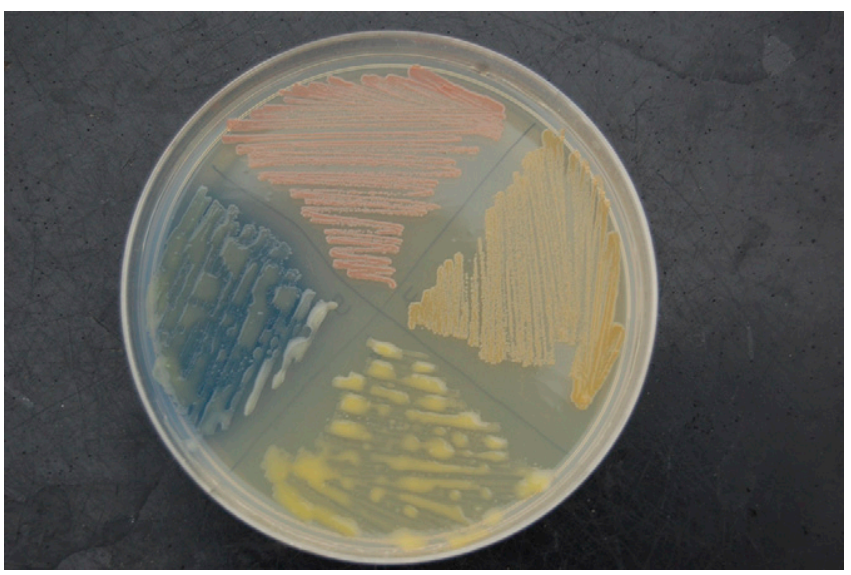

Fig. 15. Curtobacterium flaccumfaciens pv. flaccumfaciens color variants in culture (reading clockwise from top) pink, orange, yellow, purple.
Following the 2007 growing season, a pink bacterial isolate closely resembling the wilt pathogen was recovered from an orange-stained seed that originated from research plots at the Scottsbluff Ag Lab, a research farm for University of Nebraska's Panhandle Research and Extension Center, located northwest of Scottsbluff, NE. The bacterium's identity was confirmed as Curtobacterium flaccumfaciens pv. flaccumfaciens based on the same morphological and physiological characteristics (Harveson and Vidaver 2008) as previously described. Pathogenicity tests revealed the pink strain to be highly virulent to dry beans, producing indistinguishable symptoms when compared with a standard known virulent orange isolate (Fig. 18) (Harveson and Vidaver 2008).

The pink wilt variant, like that of the orange strain, is very stable and retains its colony color (Fig. 15, top) and virulence from the original isolation through multiple culture transfers and reisolations from inoculated plants. Additional bean-pathogenic, pink isolates have recently been obtained in 2012 from corn leaves infected with the bacterial pathogen Clavibacter michiganensis subsp. nebraskensis, causal agent of Goss' wilt and leaf blight (see alternant hosts below) and pink-stained dry bean seeds after the 2014 season (Fig. 14 , inset).

\section{Geographic Distribution of Curtobacterium flaccumfaciens pv. flaccumfaciens}

The exact distribution of the wilt pathogen today is uncertain, but it has been identified and reported from Alberta and Ontario provinces

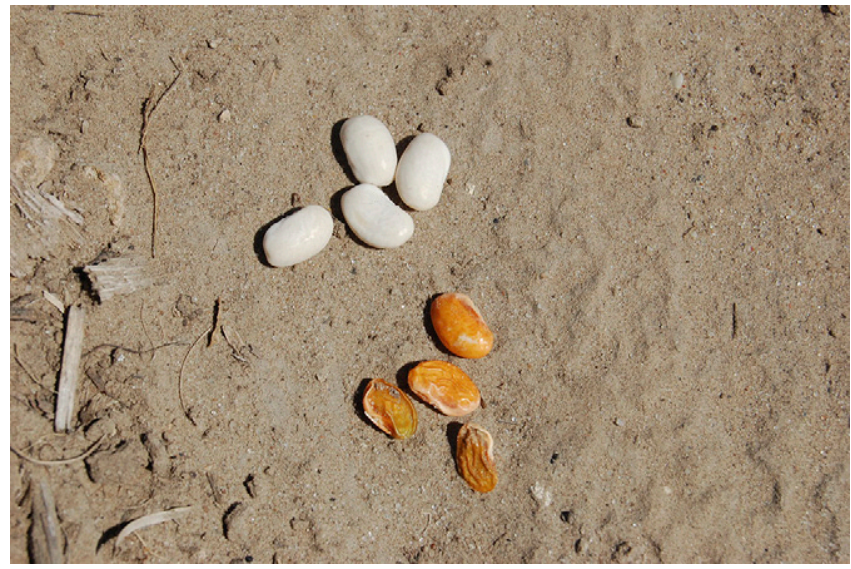

Fig. 16. Discolored seeds from a single wilt-infected plant surviving to harvest, compared with unaffected seeds from the same plant.

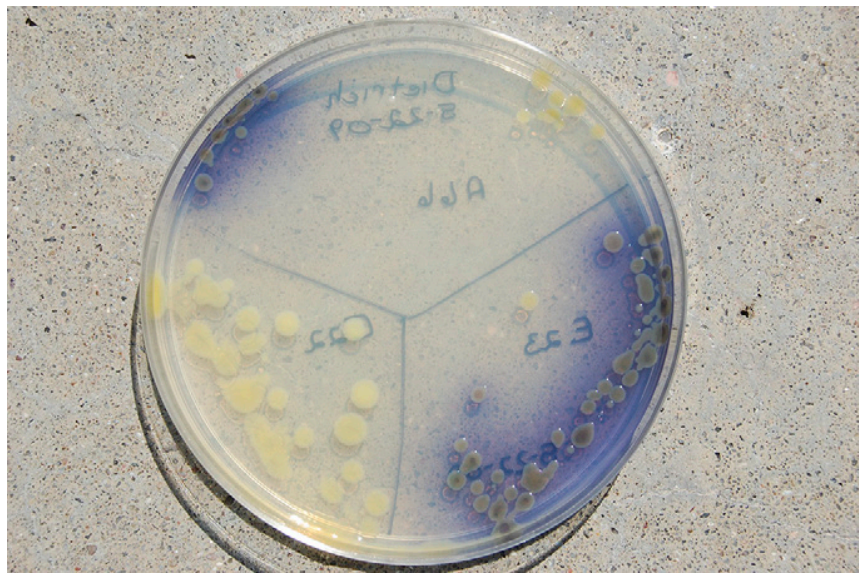

Fig. 17. Bean wilt pathogen (purple color variant) growing in culture. Note the purple to blue pigments diffusing into media from well-defined yellow colored colonies. Also note the adjacent yellow colonies from another isolate not producing the purple pigments. 
in Canada (Hsieh et al. 2002), Australia, South Africa, Mexico, Brazil, and Tunisia (Zaumeyer and Thomas 1957). Although it also has been reported from numerous European Union countries including Belgium, Bulgaria, Greece, Romania, Russia, Hungary, Poland, Turkey, and the Ukraine (EPPO/CABI 1997; Zaumeyer and Thomas 1957), it did not become established in those countries and is now considered to be absent. Apart from a report of the disease in a few fields in southeastern Spain in 2005, no other recent records of the pathogen have been acknowledged from the EPPO region. Harveson (unpublished data) recently isolated, identified, and completed Koch's postulates with strains of the pathogen originating from infected, discolored navy bean seeds grown in Iowa, Michigan, and Minnesota.

\section{Recent Studies on Bacterial Wilt}

Incidence and distribution surveys. Since 2004, extensive disease surveys led to the identification the pathogen from more than 500 fields throughout Nebraska, Colorado, and Wyoming. Thus it now appears that the disease is well established in the region. The region includes all the bean-growing areas in Nebraska (13 counties ranging from the panhandle in the west to far northeastern Nebraska to southwestern Nebraska near Kansas), southeastern Wyoming, northeastern Colorado and the front range, and the seed fields on the western slope of Colorado. The disease has been identified from multiple seed sources and dry bean market classes, including yellow, great northern, pinto, kidney, black, navy, small red, cranberry, and Anasazi. Disease incidence within fields varied widely, from $>90 \%$ to trace levels.

A novel survival mechanism for the bacterial wilt pathogen? In the process of conducting the wilt distribution surveys, soybean plants exhibiting wilting, yellowing (Fig. 19), and necrotic leaf symptoms (Fig. 20) similar to those of dry bean wilt were observed from four separate, widespread counties in western Nebraska (Box Butte, Keith, Perkins, and Scotts Bluff) during the 2005 to 2006 growing seasons. Bacteria isolated from wilted and necrotic stems and foliage were identified as $C$. flaccumfaciens pv. flaccumfaciens as described above, based on morphological and cultural features, reaction to biochemical tests, and carbon source utilization in the Biolog assays.

Repeated disease inoculations in all combinations revealed that the soybean isolates in question were pathogenic to both soybeans and dry beans. Recently collected dry bean isolates of the pathogen, when inoculated on susceptible soybean plants, also produced wilting, necrosis, and firing symptoms. However, differences were observed in virulence. Regardless of the dry bean and soybean isolates of the pathogen used, dry beans were more susceptible than soybeans, and both soybean and dry bean isolates were more virulent on dry beans than soybeans (Harveson and

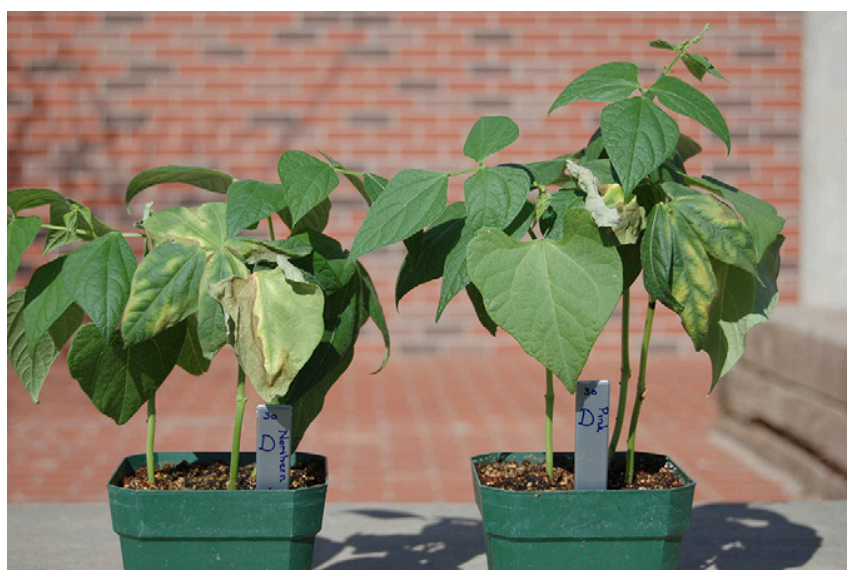

Fig. 18. Comparison of symptoms from plants inoculated with pink (left) and a standard highly virulent orange (right) isolate 15 days post-inoculation.
Vidaver 2007). Soybeans inoculated with either soybean or dry bean isolates were never completely killed, but did exhibit obvious symptoms of disease that developed more slowly than on dry beans (Fig. 21). For example, symptoms on 1-month-old plants appeared within 2 weeks for dry beans and 5 weeks for soybeans. Symptom development in younger plants (1st trifoliolate) began 8 to 9 days after inoculation in dry beans while it took

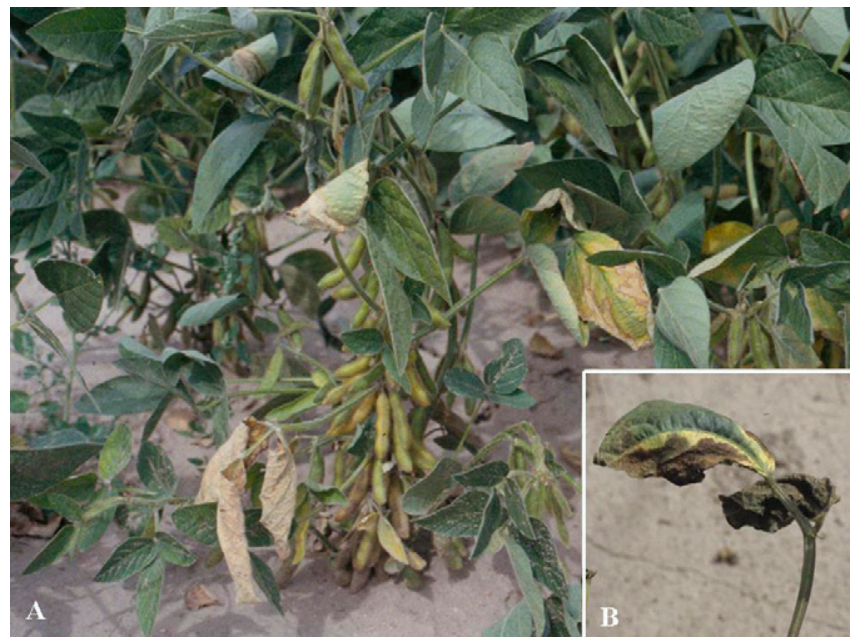

Fig. 19. Yellowing, wilting, and firing (inset) symptoms of bacterial wilt infection in soybeans.

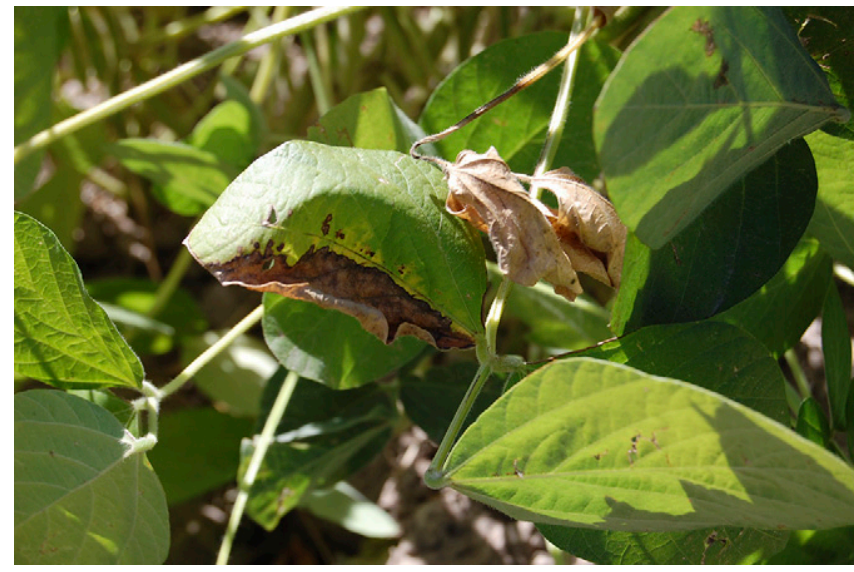

Fig. 20. Firing symptoms on soybean leaf from bacterial wilt infection.

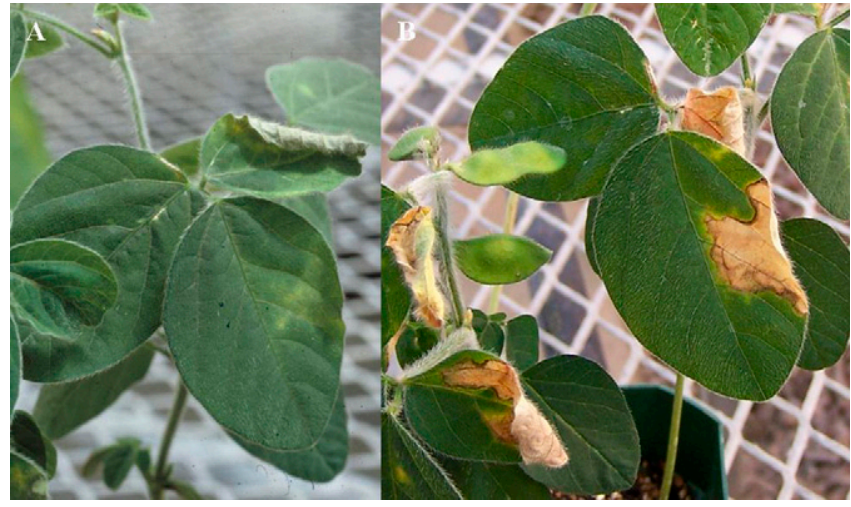

Fig. 21. Soybean plants inoculated (see Fig. 29) with bacterial wilt isolate obtained from infected soybeans A, 20 days post-inoculation, and B, 30 days postinoculation. 
14 days before symptoms were noticed in soybeans (Harveson and Vidaver 2007).

Over this same period, additional suspected bacterial wilt isolates associated with other crops (wheat and corn) grown in rotation with dry beans were discovered in Nebraska production fields, often following a dry bean crop (Harveson 2009; Harveson and Vidaver 2009). The first isolate was found in 2005 from corn leaves also infected with the Goss' wilt pathogen (Clavibacter michiganensis subsp. nebraskensis). This field had been sown to dry beans in 2004, and the crop had been severely affected by bacterial wilt. The following year (2006), bacterial wilt-infected dry bean volunteers from the previous season were identified within wilt-symptomatic soybean fields (Fig. 22), and more wilt-like isolates were obtained from Goss' wilt-infected corn leaves. Isolates recovered from bean volunteers, corn (Fig. 23), and soybean (Fig. 24) plants induced bean wilt symptoms when inoculated on kidney, great northern, and yellow beans under greenhouse conditions (Harveson 2009; Harveson and Vidaver 2009). Further pathogenicity testing with additional isolates from wheat (Fig. 25) and corn also resulted in wilting and necrotic leaf symptoms in dry beans after repeated inoculations under growth chamber and greenhouse conditions (Harveson 2009; Harveson and Vidaver 2009). The wheat crop yielding the pathogenic bacterial isolate during the 2006 study originated

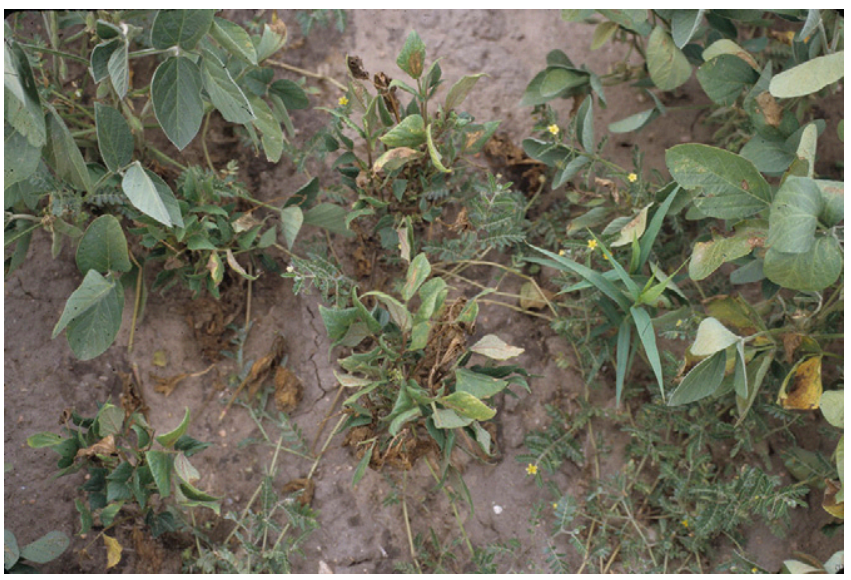

Fig. 22. Bacterial wilt-infected volunteer dry bean plants (smaller plants in the center) from the previous year's crop emerging within a soybean field the following season. Wilt isolates were recovered from adjacent symptomatic soybean plants.

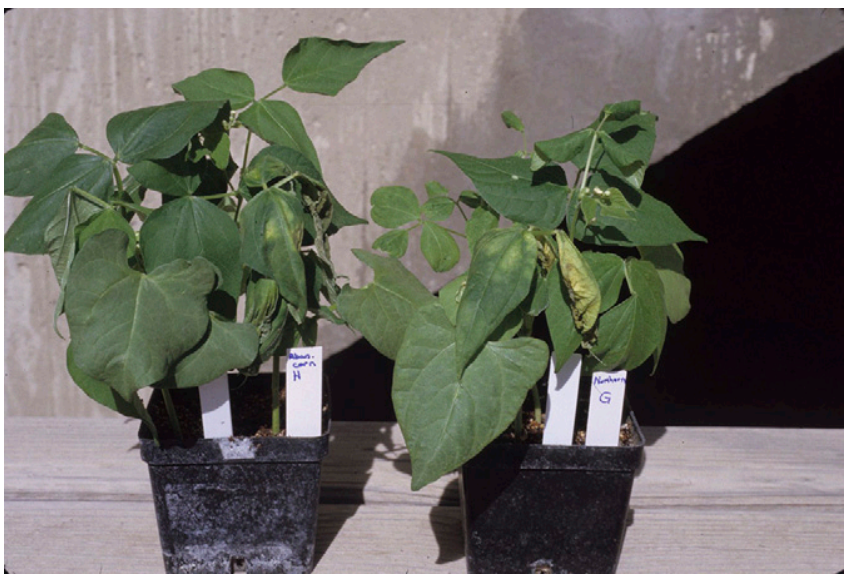

Fig. 23. Dry bean (great northern) plants inoculated with a wilt isolate from corn (left) compared with a known highly virulent orange dry bean isolate (right) (see Fig. 26). from a field planted with dry beans in 2005 . The pathogenic isolates obtained from corn in 2006 were found in volunteer corn plants growing in a severely infected dry bean field that had been abandoned (Fig. 26).

\section{Alternate Crops Survey in Nebraska}

Based on these preliminary observations, a comprehensive disease survey was conducted in 2008, 2009, and 2010 specifically looking for bean wilt isolates associated with bacterial infections of other crops grown in rotation with dry beans. The surveys covered 548 fields/sites from which 915 plant samples from 20 different crop species, including proso and foxtail millet, dry beans, sunflower, sugar beet, wheat, corn, soybean, alfalfa, and various weeds along field borders and ditches were collected (Harveson, unpublished data). The survey included fields in 10 of the 11 counties in the panhandle and Keith, Chase, and Perkins counties in southwestern Nebraska. Suspect plant samples were chosen based on foliar symptoms consistent with bacterial infections (Fig. 27). Bacterial isolates recovered from the samples were obtained either by culturing on standard growth media (NBY) or were incubated in a humidity chamber. As bacterial growth emerged from symptomatic tissues, they were restreaked on new media and observed for colony growth characteristics and color (Fig. 28). All recovered isolates were then tested for the Gram stain reaction using the $\mathrm{KOH}$

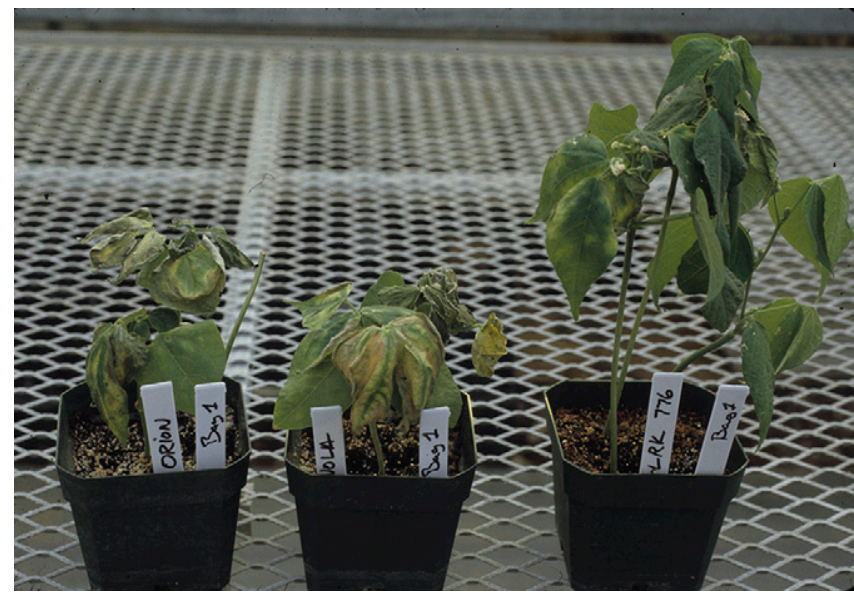

Fig. 24. Dry bean plants in market classes great northern (left), yellow (center), and light red kidney (right) inoculated with a soybean isolate.

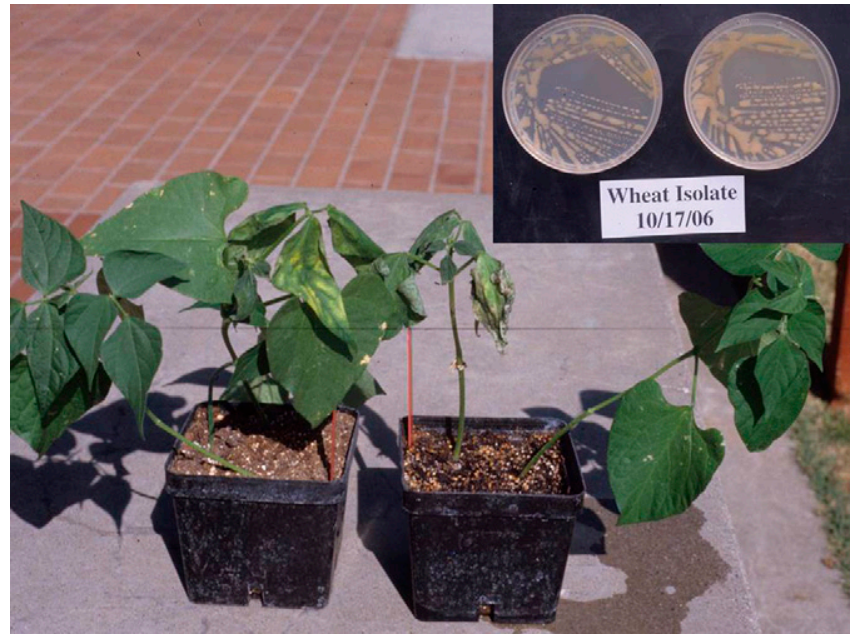

Fig. 25. Dry bean (great northern) plants inoculated with an orange isolate (inset) recovered from a black chaff-infected wheat plant. 
test and the standard Gram stain procedure using crystal violet, iodine, and safranin.

All resulting Gram-positive isolates were then tested for pathogenicity on dry beans. Plants were inoculated at the V2 stage of development (van Schoonhoven and Pastor-Corrales 1987) based a method by Rickard and Walker (1965). Inoculations consisted of dipping sterile needles into bacterial colonies from 48-h cultures and inserting into stems between the first and second node or just below the first fully expanded trifoliolate (Fig. 29), followed by incubation in lighted growth chambers with a 12-h light/dark cycle and a temperature of $30^{\circ} \mathrm{C}$ (Harveson and Vidaver 2007, 2008; Urrea and Harveson 2014).

Samples producing symptoms of bacterial wilt were reisolated and identified with bacterial cell morphology (Gram-positive, short, coryneform-type rods) and the Biolog system as previously described (Harveson, unpublished data).

As a result of the 3-year survey, in combination with those initial samples noted between 2005 and 2007, more than two dozen bean wilt isolates (26) associated with bacterial infections of five crops grown in rotation with beans were identified and recovered. The crops included wheat, corn, sunflower, soybean, and alfalfa (Harveson, unpublished data). This suggests that the pathogen is widely

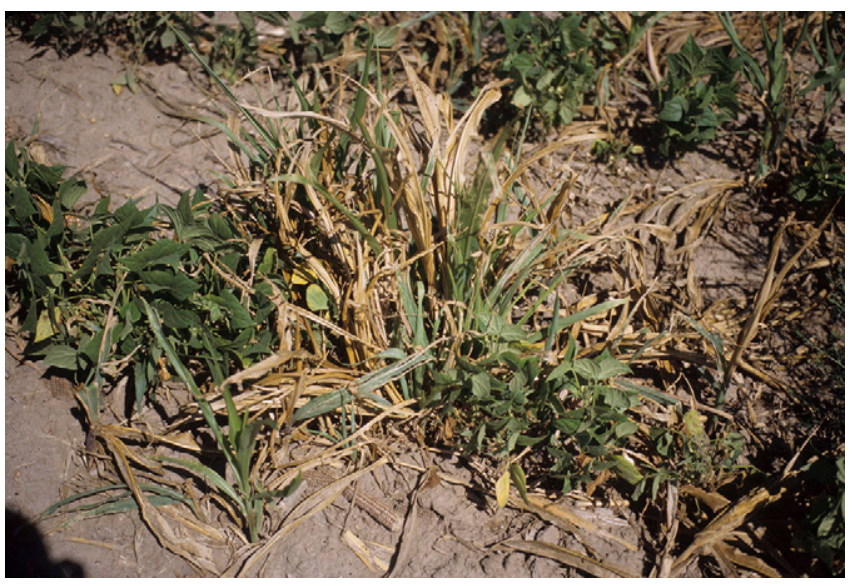

Fig. 26. Goss'wilt-infected volunteer corn plants emerging from a dry bean field that was abandoned. Curtobacterium flaccumfaciens pv. flacumfaciens (bacterial wilt) isolates were obtained from the corn plants that were also pathogenic on dry bean plants (see Fig. 23)

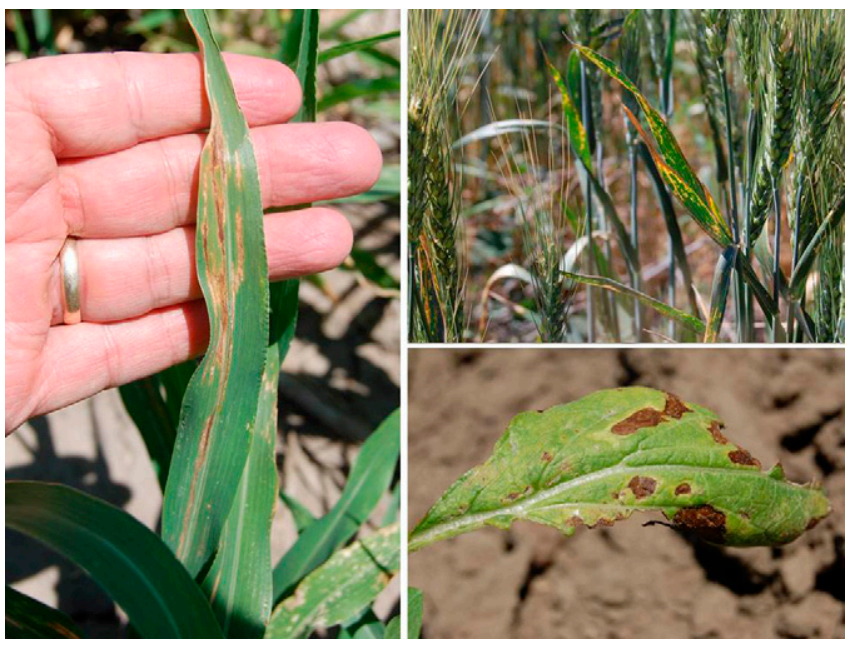

Fig. 27. Foliar symptoms characteristic of various common bacterial infections on plants included in the bacterial wilt survey on crops grown in rotation with dry beans. Crops included, clockwise starting on the left: proso millet, wheat, and sunflower. Bacterial wilt (Curtobacterium flaccumfaciens pv. flaccumfaciens) isolates were discovered occurring in association with the other bacterial diseases. distributed throughout western Nebraska production fields, and also demonstrates that it is fully capable of surviving in previous crop residues or currently growing crops, lying in wait for another dry bean crop to be planted.

\section{Comparative Irrigation Studies}

In the summer of 2003, a subsurface drip irrigation system was installed in a research field at the Scottsbluff Ag Lab and planted to dry beans. In 2004, this same field was planted back to dry beans with a great northern cultivar, 'Orion,' in mid-June. Due to the irrigation tape being off-center with planted rows that year, the emerging seedlings were severely stressed early from lack of water (Fig. 30). In late July, bacterial wilt was found suddenly and severely infesting this field with greater than $90 \%$ disease incidence and 15 to $20 \%$ plant mortality. This epidemic resulted in substantial economic losses estimated to be 60 to $65 \%$ yield reduction than expected, with another 10 to $15 \%$ of seeds in the hopper after harvest being stained yellow or orange (Fig. 31).

Another adjacent research/production field (furrow-irrigated) was planted with seed at the same time from the same cultivar and seed lot as the drip field. However, very little disease was noted in this field (several isolated plants exhibiting wilting and foliar necrosis). The only major differences between the two fields were the irrigation method employed and early stress to

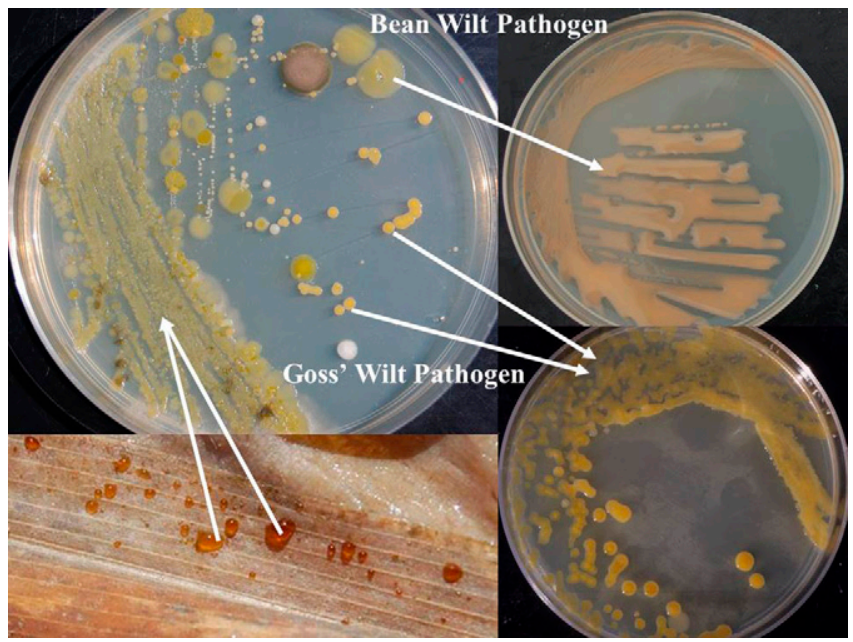

Fig. 28. Bacterial colonies emerging from Goss' wilt-infected corn leaf (lower left) maintained in a humidity chamber, and streaked on media to illustrate the methodology for separation and identification of different pathogens present in bacterial-infected leaves.

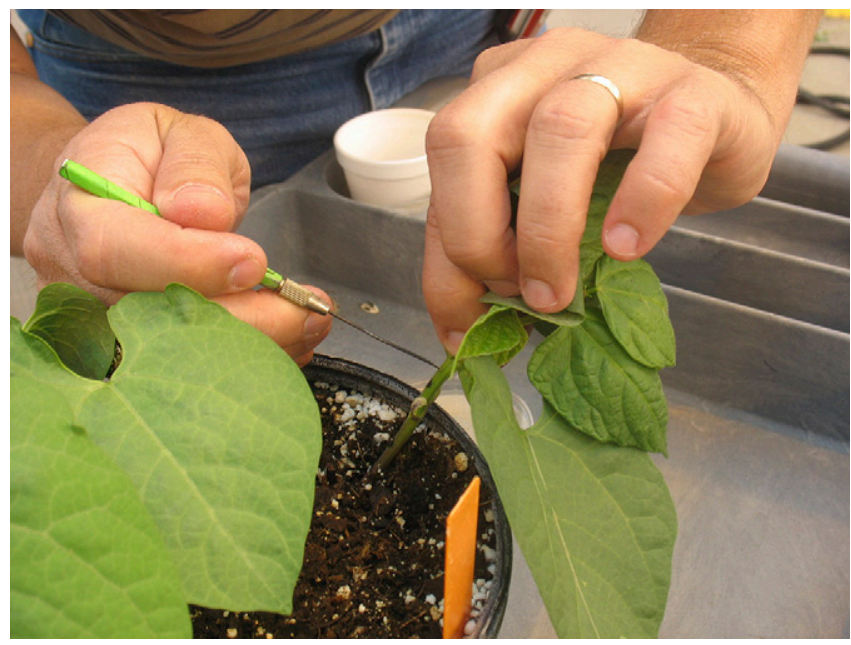

Fig. 29. Inoculating dry bean plants with the bacterial wilt pathogen. 
seedlings in the drip irrigation field. Based on these empirical observations, it was also hypothesized that the reason for high infestation in this field was that the drip irrigation may have contributed to greater disease development and spread plant to plant through the soil.

These factors presented a unique opportunity to test this idea using the drip irrigation research capabilities and compare it to other standard methods of irrigation in this region and document their influence on disease and dry bean yields in a field where the pathogen had presumably become established (Harveson and Yonts 2007).

This same field was planted back into dry beans in 2005, making it the third consecutive year for dry bean cultivation, with the purpose of comparing the three methods of irrigation (subsurface drip, furrow, and sprinkler) simultaneously in side-by-side plots (Fig. 32). All treatments resulted in very poor yields (1,105, 594, and $953 \mathrm{~kg} / \mathrm{ha}$ for drip, sprinkler, and furrow irrigation, respectively). As a comparison, another production field employing sprinkler adjacent to the drip research field produced $3,600 \mathrm{~kg} / \mathrm{ha}$ using the same cultivar. Over the next 3 years (2006 through 2008), this experiment was repeated by planting a second bean crop in the same area planted to beans the previous year. A second identical experiment was conducted simultaneously each year by sowing beans into plots following a corn crop the previous season to evaluate the effect of rotating out of dry beans for a year (Harveson and Yonts 2007).

Disease pressure was exceedingly high all seasons, particularly from the dry bean on dry bean treatments. Results indicated that the drip irrigation treatments tended to achieve higher yields and lower disease parameters compared with the sprinkler treatment,

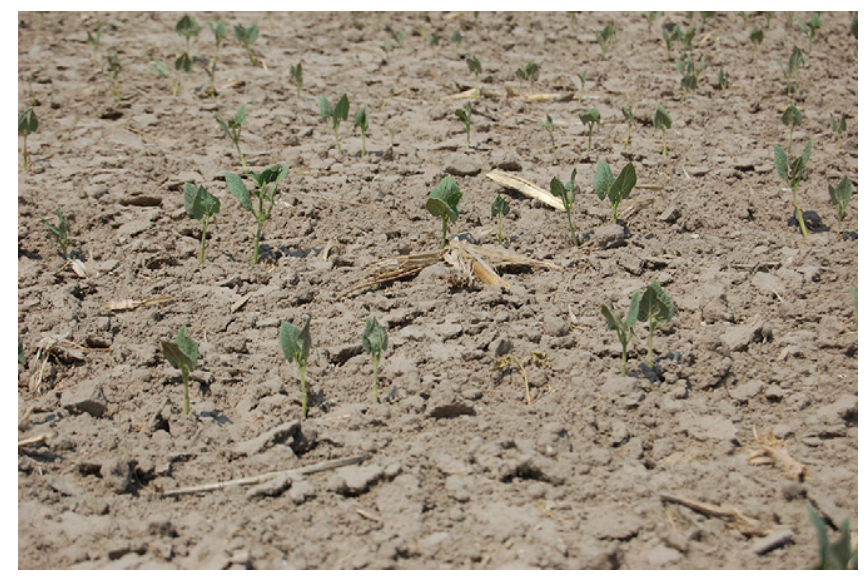

Fig. 30. Symptoms of drought stress in young dry bean seedlings.

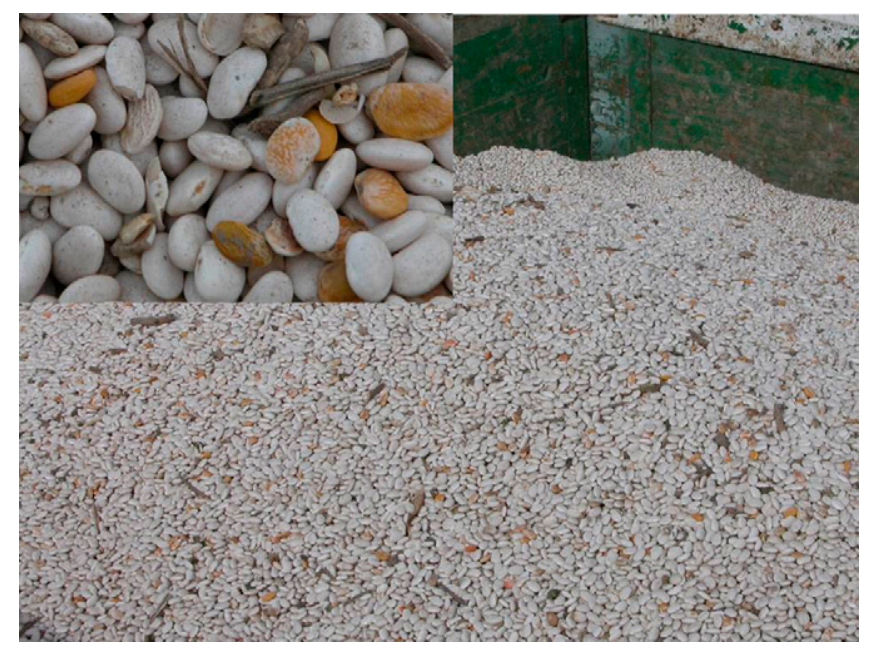

Fig. 31. Wilt-infected, stained seeds in combine bin after harvest that serve as an overwintering source for the pathogen. whereas furrow irrigation generally produced intermediate effects between the other two irrigation methods. The experiment following corn consistently produced better overall results than those following dry beans, as would be expected. There was no evidence showing any firm relationship between irrigation and the movement of the bacterium through soil water in the field.

\section{Genetic Diversity Investigations}

Few genetic studies of $C$. flaccumfaciens pv. flocumfaciens have been published as none of the various pathovars have been sequenced. The limited genotyping research that has been done has primarily focused on distinguishing among different pathovars of C. flaccumfaciens. An extensive degree of diversity and heterogeneity among strains from outside of North America have been demonstrated at both the genetic and protein levels through serology, repetitive extragenic palindromic (rep)-PCR, amplified fragment length polymorphism (AFLP), and pulsed-field gel electrophoresis (PFGE). However, they have generally employed a limited number of bacterial isolates (de Souza et al. 2006; Guimarães et al. 2003; McDonald and Wong 2000).

Agarkova et al. (2012) recently conducted similar studies utilizing 67 C. flaccumfaciens pv. flaccumfaciens isolates originating from the Central High Plains of the United States (western Nebraska, northeastern Colorado, and southeastern Wyoming) collected between 1957 and 2009, some of which were isolated from hosts other than dry beans. The genetic diversity and population structure of this group of isolates was determined using three molecular typing methods, including AFLP, rep-PCR, and PFGE. Additionally, this study was able to uniquely compare modern isolates acquired from the epidemics since 2004 with archived historical isolates collected $50+$ years ago.

The dry bean pathogen from this region was shown to be extremely diverse phenotypically and genotypically, most readily illustrated by the different pathogen color variants. Cluster analysis of a data set including the averages of all three techniques produced two distinct groups. One group included isolates with colonies of yellow, orange, or pink colors, while the other group included only yellow variants. However, there were yellow isolates producing the purple pigments that belonged to both groups. Thus this group of strains from the Central High Plains was found to be highly heterogeneous with no discernable patterns of changes in genetic structure or pathogenicity emerging between years or geographical location of original acquisition over the last 50 years (Agarkova et al. 2012).

\section{Resistance and Breeding}

The resistant great northern cv. Emerson was developed in the 1970 s by the University of Nebraska specifically for controlling

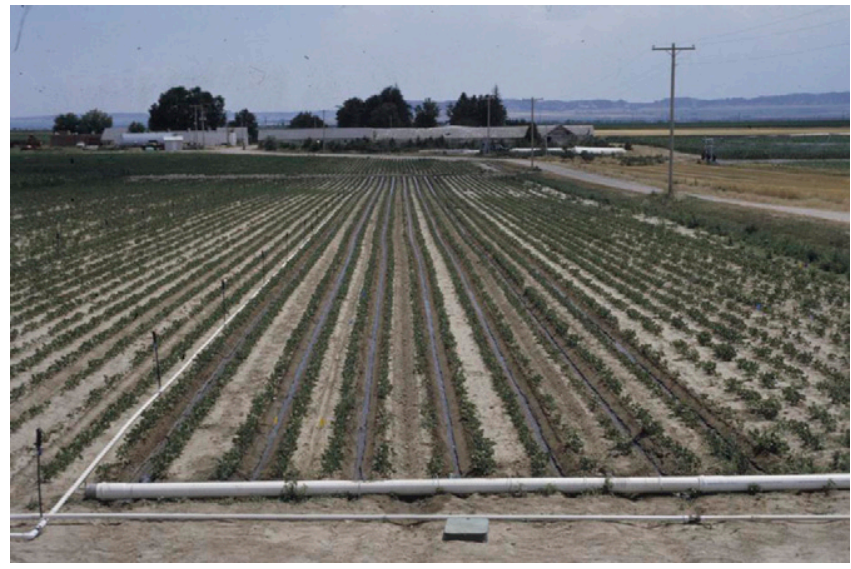

Fig. 32. Irrigation study plots demonstrating the three irrigation methods in a side-by side comparison: sprinkler (left), furrow (middle), and subsurface drip (right). Each plot was 12 rows (on $55 \mathrm{~cm}$ centers) wide and 120 meters long. 
bacterial wilt, which demonstrates the importance that this disease once held (Urrea and Harveson 2014). Breeding for resistance to this disease was later discontinued when it was determined that using seed sanitation, increasing disease-free seed in dry climates, and using proper crop rotations effectively reduced the previously severe disease issues due to bean wilt (Urrea and Harveson 2014).

\section{New Resistance Development}

While the bacterial wilt-resistant cv. Emerson is still available today, it is grown on a limited basis as a specialized variety for targeted markets in Europe and cannot be produced on every field where the disease has recently been identified. As a result, we are faced with an emerging problem that needs to be addressed using newly developed resistant cultivars (Schwartz et al. 2010; Urrea and Harveson 2014).

Through funding from the Nebraska Dry Bean Commission, and the Nebraska Department of Agriculture, 424 accessions from the North American Dry Bean Core Collection have been screened for resistance to bacterial wilt (Table 1). Only one wild bean from that collection, with very small seed size (roughly 6,000 seeds per kilogram), was identified as a source of bacterial wilt resistance. Unfortunately, it will take at least five to six backcrosses to recover the normal seed size if that wild bean is used as a source of resistance.

The International Center for Tropical Agriculture (CIAT) Common Bean Core Collection, composed of 1,700 accessions, has additionally been screened with the most virulent Nebraska bacterial wilt isolate originally obtained from great northern beans from the subsurface drip irrigation field. Of the 1,700 accessions planted, $1,685(99.12 \%)$ were susceptible to bacterial wilt, and $15(0.88 \%)$ showed some resistance to bacterial wilt. The 15 accessions showed resistance against seven additional pathogen isolates. Of those accessions, eight were wild beans, with the remainder consisting of $P$. coccineus (4), P. acutifolius (1), and cultivated (2) (Urrea and Harveson, unpublished data). Studies of bacterial wilt resistance inheritance and genetic mapping are currently being initiated, with the purpose of determining whether the source of resistance for the two cultivars is different from that of 'Emerson.' Recombinant inbred line populations are in the process of development and will be screened for reaction separately to multiple yellow, purple, pink, and orange bacterial wilt isolates.

\section{Summary and Conclusions}

The resurgence of the dry bean bacterial wilt disease in Nebraska and other areas of the high plains after a long absence has been a puzzling development. Because of the historical seedborne nature of this problem, it raises the question of whether seed sanitation in areas of increase has been forgotten or ignored. When the disease was rediscovered in two fields in Nebraska late in the 2003 season, it was assumed to be an isolated incident. However, the next season the pathogen was widespread throughout western Nebraska production fields (partially explained by the introduction of the infected seeds in the highly susceptible yellow bean cv. Enola), and has now been identified from well over 500 dry bean fields across this region since 2004 (Harveson 2015; Harveson et al. 2006).

Table 1. Bacterial wilt (BW) severity ratings of selected North American dry bean core collection breeding lines and current great northern and pinto cultivars against a virulent Nebraska orange pathogen variant. This strain was isolated originally from an infected great northern bean plant and was evaluated at the Panhandle Research and Extension Center (PREC) at Scottsbluff, NE greenhouse facilities from 2007 to 2009

\begin{tabular}{|c|c|c|c|c|}
\hline Accession & Origin & Type & Seed color/market class & BW severity (1-9) ${ }^{\mathrm{a}}$ \\
\hline & & & & Resistant \\
\hline PI 325691 & Mexico & Wild & Gray mottle & 1.0 \\
\hline Emerson & United States & Cultivated & Great northern & $\begin{array}{c}1.0 \\
\text { Intermediate }\end{array}$ \\
\hline PI 313490 & Mexico & Landrace & Black & 4.0 \\
\hline PI 201329 & Mexico & Landrace & Brown & 4.0 \\
\hline PI 313444 & Mexico & Landrace & Black & 4.0 \\
\hline PI 318695 & Mexico & Wild & Gray mottle & 4.0 \\
\hline PI 313709 & Mexico & Cultivated & Black & 4.0 \\
\hline PI 325687 & Mexico & Wild & Brown & 4.0 \\
\hline PI 325750 & Mexico & Cultivated & Bayo & 4.0 \\
\hline PI 195402 & Guatemala & Landrace & White & 4.0 \\
\hline PI 313397 & Mexico & Landrace & Bayo & 4.0 \\
\hline PI 136725 & & & White & 5.0 \\
\hline PI 165078 & Turkey & Cultivated & White & 5.0 \\
\hline PI 310761 & Guatemala & Landrace & Navy & 5.0 \\
\hline PI 325685 & Mexico & Wild & Black & 5.0 \\
\hline Coyne & United States & Cultivated & Great northern & 5.0 \\
\hline PI 313373 & Mexico & Landrace & Brown mottle & 5.0 \\
\hline PI 313512 & Mexico & Landrace & Bayo & 5.0 \\
\hline GN 99136 & United States & Experimental line & Great northern & 5.0 \\
\hline PI 207253 & Colombia & Landrace & Black mottle & 5.0 \\
\hline PI 209498 & Costa Rica & Landrace & Black mottle & 5.0 \\
\hline PI 313671 & Ecuador & Cultivated & Yellow mottle & 5.0 \\
\hline Beryl-R & United States & Cultivated & Great northern & 5.0 \\
\hline Gemini & United States & Cultivated & Great northern & 5.0 \\
\hline Marquis & United States & Cultivated & Great northern & $\begin{array}{c}7.0 \\
\text { Susceptible }\end{array}$ \\
\hline Orion & United States & Cultivated & Great northern & 7.0 \\
\hline $\mathrm{LaPaz}$ & United States & Cultivated & Pinto & 8.0 \\
\hline Average & & & & 7.0 \\
\hline LSD 0.05 & & & & 2.5 \\
\hline
\end{tabular}


The climatic patterns observed throughout the region over this period (Tables 2 and 3) may have contributed to the re-emergence of the bean wilt disease. The early to mid-2000s were characterized by warmer winters and an extended drought with increasingly higher summer temperatures during the growing season. The average maximum July temperature for 2002 to 2006 was about $1{ }^{\circ} \mathrm{C}$ higher than the 25 and/or 50 year average at Holyoke, CO and Scottsbluff, NE, while the average temperatures for January were about $3^{\circ} \mathrm{C}$ higher for the same locations (Table 2). Furthermore, the 2002 to 2006 annual precipitation level was 7.5 to $9 \mathrm{~cm}$ lower than the 25 and/or 50 year annual averages at Holyoke and Scottsbluff (Table 3). These factors easily could have enhanced conditions conducive both for pathogen survival and increased plant stresses, which are well recognized to favor wilt disease development and severity.

Changes in cultural practices adopted in this region over the last 15 to 20 years may also have played a critical role in this mystery. The majority of the region's producers now use some form of reduced tillage. Combining this practice with the simultaneous, region-wide increases in center pivot sprinkler irrigation systems could provide conditions enhancing pathogen survival, infection, and dispersal within fields.

In summary, it is likely that wilt has "reappeared" and become widely established throughout the dry bean production areas in this region, due in part to recent changes in cultural practices, although other factors have undoubtedly also played a role. It also seems likely that the pathogen never disappeared completely, but was able to survive at low levels as a saprophyte on weeds, other crop species, or plant residues. In the past, most fields were routinely plowed each season (removing a major source of survival), and may not have been noticed. It is also logical to hypothesize that the disease was simply overlooked (or misidentified) because symptoms of wilt are reminiscent of and potentially confused with common bacterial blight (Fig. 8). The recent data collected and presented here strongly suggest that the return of bean wilt throughout the Central High Plains over the last decade is not due to a single factor but a combination of new changes in cultural practices, environmental stresses, and unfamiliarity with the pathogen and its past history.

Table 2. Average January and July temperatures for the time period of the re-emergence of bacterial wilt (2002 to 2006) compared with the 25 year and 50 year averages in Holyoke, CO and Scottsbluff, NE

\begin{tabular}{lccc}
\hline Location & Time period & January & July \\
\hline Holyoke, CO & & & \\
& $1987-2011$ & $4.7^{\circ} \mathrm{C}$ & $30.7^{\circ} \mathrm{C}$ \\
& $1961-2011$ & $4.6^{\circ} \mathrm{C}$ & $31.7^{\circ} \mathrm{C}$ \\
Scottsbluff, NE & $2002-2006$ & $7.4^{\circ} \mathrm{C}$ & $32.5^{\circ} \mathrm{C}$ \\
& & & \\
& $1987-2011$ & $4.7^{\circ} \mathrm{C}$ & $32.2^{\circ} \mathrm{C}$ \\
& $1961-2011$ & $3.8^{\circ} \mathrm{C}$ & $32.2^{\circ} \mathrm{C}$ \\
& $2002-2006$ & $7^{\circ} \mathrm{C}$ & $33.9^{\circ} \mathrm{C}$ \\
\hline
\end{tabular}

Table 3. Average yearly precipitation levels for the time period of the re-emergence of bacterial wilt (2002 to 2006) compared with the 25 year and 50 year averages in Holyoke, $\mathrm{CO}$ and Scottsbluff, NE

\begin{tabular}{lcc}
\hline Location & Time period & Average $(\mathrm{cm})$ \\
\hline Holyoke & $1987-2011$ & 45.2 \\
& $1961-2011$ & 44.5 \\
Scottsbluff & $2002-2006$ & 35.9 \\
& $1987-2011$ & 39.8 \\
& $1961-2011$ & 39.0 \\
& $2002-2006$ & 31.6 \\
\hline
\end{tabular}

\section{Literature Cited}

Agarkova, I. V., Lambrecht, P. A., Vidaver, A. K., and Harveson, R. M. 2012 Genetic differentiation of Curtobacterium flaccumfaciens pv. flaccumfaciens populations in the American High Plains. Can. J. Microbiol. 58:788-801.

Burke, D. W. 1957a. Incidence of bacterial pathogens in dry beans in irrigated districts of Nebraska, Wyoming, and Colorado in 1954 and 1955. Plant Dis. Rep. 41:488-490.

Burke, D. W. 1957b. Bacterial wilt of pinto beans on soils of different types and cropping histories. Plant Dis. Rep. 44:671-673.

Burke, D. W., and Seliskar, C. E. 1957. Disease incidence and yields of beans in relation to cultivation injury in northeastern Colorado. Plant Dis. Rep. 41:483-487.

Burkholder, W. H. 1945. The longevity of the pathogen causing the wilt of common bean. Phytopathol. 35:743-744.

Collins, M. D., and Jones, D. 1983. Reclassification of Corynebacterium flaccumfaciens, Corynebacterium betae, Corynebacterium oortii, and Corynebacterium poinsettiae in the genus Curtobacterium as Curtobacterium flaccumfaciens comb. nov. J. Gen. Microbiol. 129:3545-3548.

Davis, M. J. 1986. Taxonomy of plant-pathogenic coryneform bacteria. Annu. Rev. Phytopathol. 24:115-140.

Davis, M. J. 2001. Coryneform phytobacteria. Pages 255-256 in: Encyclopdia of Plant Pathology. O. C. Maloy and T. D. Murray, eds. Vol. 1. John Wiley and sons, Inc., New York.

de Souza, V. L., Maringoni, A. C., and Krause-Sakate, R. 2006. Genetic variability in Curtobacterium flaccumfaciens pv. flaccumfaciens isolates. Summa Phytopathol. 32:170-176.

EPPO/CABI. 1997. Curtobacterium flaccumfaciens pv. flaccumfaciens. Pages 991-994 in: Quaratine Pests for Europe, $2^{\text {nd }}$ ed. I. M. Smith, D. G. McNamara, P. R. Scott, and $\mathrm{H}$. Holderness, eds. CAB International, Wallingford, UK.

Guimarães, P. M., Smith, J. J., Palmano, S., and Saddler, G. S. 2003 Characterization of Curtobacterium flaccumfaciens pathovars by AFLP, repPCR and pulsed-field gel electrophoresis. Eur. J. Plant Pathol. 109:817-825.

Harveson, R. M. 2009. New hosts for the dry bean bacterial wilt pathogen in western Nebraska? Phytopathology 99:52.

Harveson, R. M. 2013. The multicolored bacterium. APSnet Feature Article, November 2013

Harveson, R. M. 2015. The bacterium of many colors. APS Press, St. Paul, MN.

Harveson, R. M., and Schwartz, H. F. 2007. Bacterial diseases of dry edible beans in the Central High Plains. Plant Health Prog. doi:10.1094/PHP-2007-0125-01-DG.

Harveson, R. M., Schwartz, H. F., and Urrea, C. A. 2011. Bacterial wilt of dry beans in western Nebraska. NebGuide G05-1562-A (revised). Coop. Ext. Serv., Univ. of Nebr, Lincoln.

Harveson, R. M., Schwartz, H. F., Vidaver, A. K., Lambrecht, P. A., and Otto, K. 2006. New outbreaks of bacterial wilt of dry beans in Nebraska observed from field infections. Plant Dis. 90:681.

Harveson, R. M., and Vidaver, A. K. 2007. First report of the natural occurrence of soybean bacterial wilt isolates pathogenic to dry beans in Nebraska. Plant Health Prog. doi:10.1094/PHP-2007-0822-01-BR

Harveson, R. M., and Vidaver, A. K. 2008. A new color variant of the dry bean bacterial wilt pathogen (Curtobacterium flaccumfaciens pv. flaccumfaciens) found in western Nebraska. Plant Health Prog. doi:10.1094/PHP-2008-081501-BR.

Harveson, R. M., and Vidaver, A. K. 2009. Alternate hosts for the dry bean bacterial wilt pathogen in western Nebraska? Annu. Rept. Bean Improv. Coop. Abst. P-30. Ft. Collins, CO.

Harveson, R. M., and Yonts, C. D. 2007. Influence of irrigation method on incidence and severity of bacterial wilt of dry beans in Nebraska. Phytopathology 97:S45.

Hedges, F. 1922. A bacterial wilt of the bean caused by Bacterium flaccumfaciens nov. sp. Science 55:433-434.

Hedges, F. 1926a. Bacterial wilt of beans (Bacterium flaccumfaciens Hedges) including comparisons with Bacterium phaseoli. Phytopathology 16:1-22.

Hedges, F. 1926b: Pages 165-166 in: Bean wilt traceable to infected seed. The Year Book of Agriculture, U.S. Department of Agriculture, Washington, DC.

Hsieh, T. F., Huang, H. C., Erickson, R. S., Yanke, L. J., and Mundel, H.-H. 2002. First report of bacterial wilt of common bean caused by Curtobacterium flaccumfaciens in western Canada. Plant Dis. 86:1275.

Huang, H. C., Erickson, R. S., Yanke, L. J., Chelle, C. D., and Mündel, H.-H. 2006. First report of the purple variant of Curtobacterium flaccumfaciens pv. flaccumfaciens, causal agent of bacterial wilt of bean, in Canada. Phytopathol. 90:1262.

Ishimaru, C., Mohan, S. K., and Franc, G. D. 2005. Bacterial wilt. Pages 50-52 in: Compendium of Bean Diseases, 2nd Ed., H. F. Schwartz, J. R. Steadman, R. Hall, and R. L. Forster, eds. American Phytopathological Society, St. Paul, MN

Jensen, H. L. 1934. Studies on saprophytic mycobacteria and corynebacteria Proc. Linn. Soc. N. S. W. 59:19-61.

Jensen, H. L. 1952. The coryneform bacteria. Annu. Rev. Microbiol. 6:77-90.

Leben, C. 1981. How plant-pathogenic bacteria survive. Plant Dis. 65:633-637.

Lehmann, K. B., and Neumann, R. O. 1896. Atlas und Grundriss der Bakteriologie und Lehrbuch der speziellen bakteriologishen Diagnostik, 1st ed. Lehman, Munchen, Germany.

McDonald, J. G., and Wong, E. 2000. High diversity in Curtobacterium flaccumfaciens pv. flaccumfaciens characterized by serology and rep-PCR genomic fingerprinting. Can. J. Plant Pathol. 22:17-22.

Rickard, S. F., and Walker, J. C. 1965. Mode of inoculation and host nutrition in relation to bacterial wilt of bean. Phytopathology 55:174-178. 
Ristaino, J. B. 2008. Introduction. Pages 9-11 in: Pioneering Women in Plant Pathology. APS Press, St. Paul, MN.

Schuster, M. L., and Christiansen, D. W. 1957. An orange-colored strain of Corynebacterium flaccumfaciens causing bean wilt. Phytopathol. 47:51-53.

Schuster, M. L., and Coyne, D. P. 1974. Survival mechanisms of phytopathogenic bacteria. Annu. Rev. Phytopathol. 12:199-221.

Schuster, M. L., and Coyne, D. P. 1975. Survival factors of plant pathogenic bacteria. Res. Bull. 268. Univ. of Nebraska, Lincoln, NE.

Schuster, M. L., and Sayre, R. M. 1967. A coryneform bacterium induces purplecolored seed and leaf hypertrophy of Phaseolus vulgaris and other Leguminosae. Phytopathol. 57:1064-1066.

Schuster, M. L., Vidaver, A. K., and Mandel, M. 1968. A purple pigmentproducing bean wilt bacterium Corynebacterium flaccumfaciens var. violaceum n. var. Can. J. Microbiol. 14:423-427.

Schwartz, H. F., Franc, G. D., Hanson, L. E., and Harveson, R. M. 2005 . Disease management. Pages 109-143 in: Dry Bean Production and Pest Management. H. F. Schwartz, M. A. Brick, R. M. Harveson, and G. D. Franc, eds. Bull. No. 562A, Colorado State Univ., Fort Collins, CO.

Schwarz, H. F., Brick, M. A., Otto, K., and Ogg, J. B. 2010. Germplasm evaluation for resistance to bacterial wilt in common bean, 2008-2009. Plant Dis. Manage. Rep. 4:V125.
Urrea, C. A., and Harveson, R. M. 2014. Identification of sources of bacterial wilt resistance in common beans (Phaseolus vulgaris L.). Plant Dis. 98 973-976.

van Schoonhoven, A., and Pastor-Corrales, M. A. 1987. CIAT. Standard evaluation of bean germplasm. Centro Internacional de Agricultura Tropical. CIAT, Cali, Colombia

Venette, J. R., Lamppa, R. S., and Gross, P. L. 1995. First report of bean bacterial wilt caused by Curtobacterium flaccumfaciens subsp. flaccumfaciens in North Dakota. Plant Dis. 79:966.

Vidaver, A. K. 1982. The plant pathogenic corynebacteria. Annu. Rev. Microbiol 36:495-517.

Vidaver, A. K., and Starr, M. P. 1981. Phytopathogenic coryneform and related bacteria. Pages 1879-1887 in: The Prokaryotes, A Handbook on Habitats, Isolation, and Identification of Bacteria. Springer-Verlag, Berlin-HeidelbergNew York

Zaumeyer, W. J. 1932. Comparative pathological histology of three bacterial diseases of bean. J. Agric. Res. 44:605-632.

Zaumeyer, W. J., and Thomas, H. R. 1947. Bean diseases in some of the mountain states in 1947. Plant Dis. Rep. 31:432-442.

Zaumeyer, W. J., and Thomas, H. R. 1957. A monographic study of bean diseases and methods for their control. USDA Technical Bull. 868 (revised).
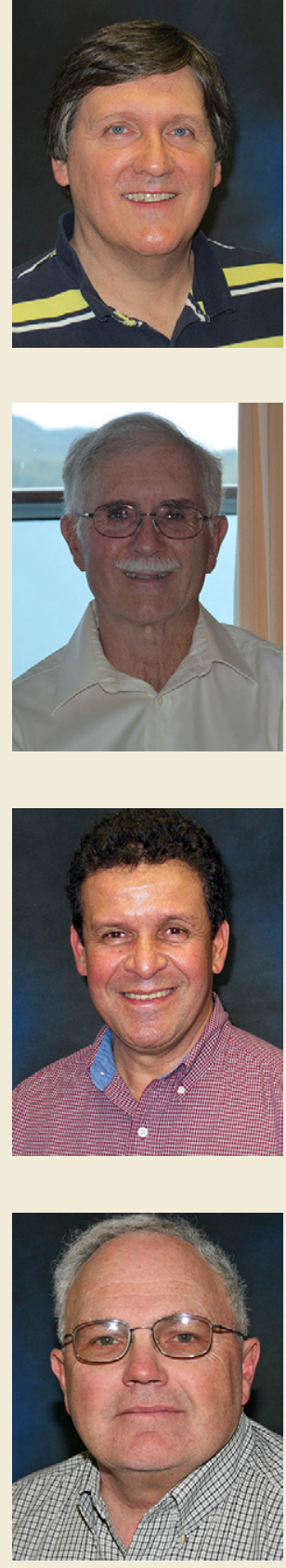

\section{Bob Harveson}

Dr. Harveson is a professor in the Department of Plant Pathology with the University of Nebraska. He received his Ph.D. in 1999 from the University of Florida. He began his current appointment located at the Panhandle Research and Extension Center in that same year as assistant professor, and was promoted to associate and full professor in 2005 and 2010, respectively. He received an M.S. degree in plant pathology in 1989 from Texas A\&M University, and then started and managed a new plant disease diagnostic clinic for the University of Florida at the SW Florida REC in Immokalee. From 1991 to 1995, he worked as a research associate with Texas A\&M University in Amarillo, investigating diseases of sugar beets. His current appointment involves $50 \%$ research and $50 \%$ extension, with programming responsibility for specialty crop diseases. His research program focuses on the etiology and applied management of sugar beet, dry bean, and sunflower diseases.

\section{Howard Schwartz}

From 1980 to 2015, Dr. Schwartz was a research and extension plant pathology specialist and Associate Dept. Head for the Department of Bioagricultural Sciences and Pest Management at Colorado State University. Responsibilities consisted of research and extension programs for major row (dry edible bean) and commercial vegetable (onion) crops grown in Colorado. Research and extension programs focused upon integrated disease management through host resistance, cultural practices, environmental monitoring, disease forecasting, and pesticide scheduling. He served as the national coordinator for the Legume ipmPIPE and Onion ipmPIPE projects in recent years with many colleagues and stakeholders.

\section{Carlos Urrea}

Dr. Urrea is an associate professor in the Department of Agronomy \& Horticulture at the University of Nebraska. He received his Ph.D. in 2000 in Plant Breeding and Genetics, minor in Statistics from North Dakota State University, and began his current appointment located at the Panhandle Research and Extension Center in 2005 . His research $(75 \%)$ and extension $(25 \%)$ efforts focus on the genetics, evaluation, and development of dry bean and chickpea cultivars adapted to western Nebraska. Screening bean germplasm for desirable agronomic traits and resistance to major abiotic and biotic stresses is integral to his breeding efforts. His breeding program is multi-faceted and includes laboratory, greenhouse, and field research at the Panhandle Research and Extension Center, the Scottsbluff Ag Lab, and cooperating growers' fields, as well as participation in multi-state/regional breeding trials, shuttle breeding efforts in Puerto Rico, and winter nurseries in New Zealand and Puerto Rico.

\section{Dean Yonts}

Mr. Yonts was an associate professor in the Biological Systems Engineering Department with the University of Nebraska and also located at the Panhandle REC in Scottsbluff as the extension irrigation engineer. He received both B.S. and M.S. degrees in agricultural engineering from the University of Wyoming. His research focused on evaluating the impact of irrigation timing and deficit irrigation strategies, comparing sprinkler and furrow irrigation systems, on yields of sugar beets and dry beans. He additionally pioneered early investigations into the agronomic potential for utilizing sub-surface drip irrigation in dry bean and corn production in the central high plains of the U.S. Mr. Yonts passed away on July 6, 2012, after an extended battle with leukemia. 